\title{
Impact of aftertreatment devices on primary emissions and secondary organic aerosol formation potential from in-use diesel vehicles: results from smog chamber experiments
}

\author{
R. Chirico ${ }^{1,2}$, P. F. DeCarlo ${ }^{1}$, M. F. Heringa ${ }^{1}$, T. Tritscher ${ }^{1}$, R. Richter ${ }^{1}$, A. S. H. Prévôt ${ }^{1}$, J. Dommen ${ }^{1}$, \\ E. Weingartner ${ }^{1}$, G. Wehrle ${ }^{1}$, M. Gysel ${ }^{1}$, M. Laborde ${ }^{1}$, and U. Baltensperger ${ }^{1}$ \\ ${ }^{1}$ Laboratory of Atmospheric Chemistry, Paul Scherrer Institut, 5232 Villigen PSI, Switzerland \\ ${ }^{2}$ Italian National Agency for New Technologies, Energy and Sustainable Economic Development (ENEA), FIS-LAS, \\ Via E. Fermi 45, 00044 Frascati, Italy
}

Received: 9 June 2010 - Published in Atmos. Chem. Phys. Discuss.: 30 June 2010

Revised: 16 November 2010 - Accepted: 20 November 2010 - Published: 6 December 2010

\begin{abstract}
Diesel particulate matter (DPM) is a significant source of aerosol in urban areas and has been linked to adverse health effects. Although newer European directives have introduced increasingly stringent standards for primary PM emissions, gaseous organics emitted from diesel cars can still lead to large amounts of secondary organic aerosol (SOA) in the atmosphere. Here we present results from smog chamber investigations characterizing the primary organic aerosol (POA) and the corresponding SOA formation at atmospherically relevant concentrations for three in-use diesel vehicles with different exhaust aftertreatment systems. One vehicle lacked exhaust aftertreatment devices, one vehicle was equipped with a diesel oxidation catalyst (DOC) and the third vehicle used both a DOC and diesel particulate filter (DPF). The experiments presented here were obtained from the vehicles at conditions representative of idle mode, and for one car in addition at a speed of $60 \mathrm{~km} / \mathrm{h}$. An Aerodyne high-resolution time-of-flight aerosol mass spectrometer (HR-ToF-AMS) was used to measure the organic aerosol (OA) concentration and to obtain information on the chemical composition. For the conditions explored in this paper, primary aerosols from vehicles without a particulate filter consisted mainly of black carbon (BC) with a low fraction of organic matter $(\mathrm{OM}, \mathrm{OM} / \mathrm{BC}<0.5)$, while the subsequent aging by photooxidation resulted in a consistent production of SOA only for the vehicles without a DOC and with a deactivated DOC. After $5 \mathrm{~h}$ of aging $\sim 80 \%$ of the total organic aerosol was on average secondary and the estimated "emission factor" for SOA was $0.23-0.56 \mathrm{~g} / \mathrm{kg}$ fuel burned. In presence of both a DOC and a DPF, only $0.01 \mathrm{~g}$
\end{abstract}

Correspondence to: A. S. H. Prévôt (andre.prevot@psi.ch)
SOA per $\mathrm{kg}$ fuel burned was produced within $5 \mathrm{~h}$ after lights on. The mass spectra indicate that POA was mostly a nonoxidized OA with an oxygen to carbon atomic ratio $(\mathrm{O} / \mathrm{C})$ ranging from 0.10 to 0.19 . Five hours of oxidation led to a more oxidized $\mathrm{OA}$ with an $\mathrm{O} / \mathrm{C}$ range of 0.21 to 0.37 .

\section{Introduction}

Since 1990 the number of new diesel passenger cars registered in Western Europe has been increasing. In 2007, 14.7 million cars were registered and $53.3 \%$ of these cars were diesel powered, compared to 50.8\% in 2006 (ACEA, February 2008). Particulate matter from diesel engines (DPM) has been a great concern in the past years. DPM contains toxic chemicals including polycyclic aromatic hydrocarbons (PAHs) which are known to cause damage to genetic material and are considered carcinogenic. These compounds can be transferred into the bloodstream after exposure to DPM (US EPA, 2002). Available evidence indicates that there are adverse health effects associated with exposure to DPM including acute exposure-related symptoms, chronic exposure-related non-carcinogenic respiratory effects, and chronic exposure-related carcinogenic effects (US EPA, 2002; Pope and Dockery, 2006).

The emission standards for diesel passenger vehicles are regulated by several European Union directives, which define increasingly stringent standards. EURO 3 (introduced in 2000) allowed a particle emission rate of $0.05 \mathrm{~g} / \mathrm{km}$ which was reduced to $0.025 \mathrm{~g} / \mathrm{km}$ in 2005 (EURO 4) and to $0.005 \mathrm{~g} / \mathrm{km}$ in 2009 (EURO 5). More information on regulations and limits can be found at http://europa.eu/legislation summaries/environment/air_pollution/index_en.htm. 
Diesel particles are a complex mixture of partially burned and unburned organic matter (OM) from fuel and lubrication oil, solid elemental carbonaceous material (EC) or when measured by optical techniques termed black carbon (BC), sulfate, ash and others (Kittelson, 1998). The emission rates of the solid carbonaceous material and OM depend on various factors: engine temperature and load, aftertreatment devices and dilution of exhaust (Sharma et al., 2005; Lipsky and Robinson, 2006; Leskinen et al., 2007; Tang et al., 2007).

Since 1998 aftertreatment devices such as diesel oxidation catalysts (DOC) have become mandatory for new diesel vehicles in Europe. DOCs were introduced to control carbon monoxide (CO) and hydrocarbons (HC). DOC may also oxidize a fraction of the organic constituents of the particulate matter resulting in a reduction of the total emitted particulate mass. The reduction in the overall particulate matter (PM) emissions is around 5-40\% depending on the relative organic content of the PM (Walker, 2004; Fino, 2007). To comply with the lower limits introduced by the European directives, different types of diesel particulate filters (DPF) have been developed. The wall-flow filter is most widely used and it has a trapping efficiency of nearly 100\% (Walker, 2004; Fino, 2007).

PM emission measurements operated with low dilution ratios likely overestimate the emitted fine particle mass because at low dilution ratios less evaporation occurs for some particle-associated organics (Robinson et al., 2007). Recent findings have shown that the mass of PM with an aerodynamic diameter less than $2.5 \mu \mathrm{m}\left(\mathrm{PM}_{2.5}\right)$ emitted by a diesel power generator with no aftertreatment devices can decrease by $50 \%$ when the dilution ratio is increased from 20:1 to 350:1 (Lipsky and Robinson, 2006). This mass reduction has been associated with semi-volatile organic compounds (SVOCs) which repartition to the gas phase with increasing dilution to maintain thermodynamic equilibrium (Lipsky and Robinson, 2006). SVOCs in the atmosphere can be involved in photochemical reactions, which often lead to products of lower volatility than the parent compounds. These compounds may contribute to the formation of secondary organic aerosol (SOA).

SOA in general is found to be a major fraction of organic aerosol (Jimenez et al., 2009; Lanz et al., 2010). Organic compounds are oxidized by reactions with oxidants like hydroxyl radicals $(\mathrm{OH})$ and ozone $\left(\mathrm{O}_{3}\right)$, and their partitioning to the particle phase as SOA can be described by an absorptive mechanism (Pankow, 1994b). Saturation vapor pressure and the organic mass loading of the aerosol are two important parameters that affect the gas/particle partitioning of organic molecules as described by the absorption model. Secondary aerosol formation, through absorption of semi-volatile organic compounds into the condensed organic phase, can occur even when the gas phase pressures of these compounds are below their saturation vapor pressures (Pankow, 1994a). As the OA concentration increases, a higher fraction of an organic species will partition to the particulate phase.
The oxidation of SVOCs can contribute to the SOA production in the atmosphere, which is often underestimated by explicit chemical models of secondary organic aerosol (Volkamer et al., 2006; Robinson et al., 2007). In fact, the oxidation of traditionally investigated SOA precursors such as light aromatics can only explain a small fraction of the SOA formed from the photooxidation of exhaust from a power generator during smog chamber experiments (Weitkamp et al., 2007). Accounting for partitioning and aging of SVOCs a considerable amount of regional SOA is predicted, which exceeds the SOA predicted by traditional models that do not take into account repartitioning of SVOCs (Robinson et al., 2007).

Currently, there is a lack of information about the secondary aerosol formation potential from in-use diesel passenger vehicles, and the effect of aftertreatment devices on the SOA formation potential. In this paper we present investigations of the contribution of emissions from diesel passenger cars to primary (directly emitted) organic aerosol (POA) and SOA formed during smog chamber experiments. The experiments presented here were obtained from one vehicle lacking aftertreatment devices, one vehicle equipped with a DOC, and one vehicle equipped with both a DOC and DPF (1 experiment only). All vehicles were tested for conditions representing engine idling. $60 \mathrm{~km} / \mathrm{h}$ conditions were simulated for the vehicle with a DOC. Characterization of POA and estimates of the SOA formation will be presented. Additionally the first high mass resolution characterization of the evolution of the aerosol mass spectra with an Aerodyne HRToF-AMS will be presented. Finally, pure SOA mass spectra from experiments with only the gas phase of the exhaust will also be shown.

\section{Materials and methods}

\subsection{Smog chamber setup and summary of general procedure and experiments}

The experiments were carried out in the smog chamber at the Paul Scherrer Institute (PSI) in Switzerland. The 27- $\mathrm{m}^{3}$ Teflon bag is temperature controlled by two cooling units which provide a stabilized temperature within the range of $20-25^{\circ} \mathrm{C}$. Four xenon arc light sources are used to simulate solar irradiation. The chamber is equipped with various instruments to monitor the gas and the particle phases during an experiment (Paulsen et al., 2005).

A new injection system was developed to deliver a representative and consistent sample of the diesel exhaust into the chamber (Fig. 1). Zero air, supplied by a pure air generation system (737-250 series, AADCO Instruments, Inc., USA), was used to rapidly dilute the exhaust by a factor of approximately 7 with an ejector diluter (Dekati Ltd., Tampere, Finland) to avoid particle coagulation. The line from the tailpipe including the ejector diluter and the dilution air 


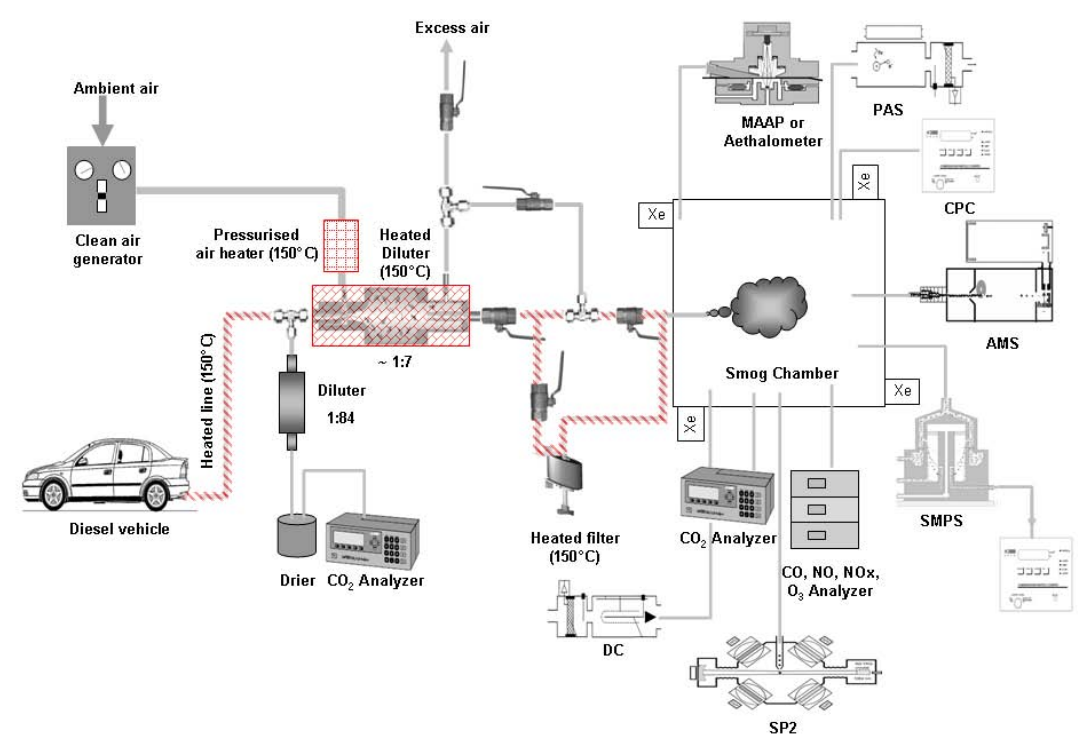

Fig. 1. Schematic representation of the sampling line, the smog chamber and the measurement setup of the smog chamber.

was maintained at $150^{\circ} \mathrm{C}$ to avoid condensation of SVOCs. A filter designed for hot gas analysis usable up to $500^{\circ} \mathrm{C}$ with a stainless steel housing (borosilicate glass microfiber filter, HC free and H131R, Headline filters), offered a method of particle free sample introduction into the smog chamber. This filtering system (heated to $150^{\circ} \mathrm{C}$ ) was used in some experiments to simulate a DPF. The filter specifications from the manufacturer indicate a removal efficiency greater than $99.5 \%$ for particles with a diameter of $100 \mathrm{~nm}$.

In addition, experiments with the sampling line and the dilution air at $80^{\circ} \mathrm{C}$ were performed to evaluate the effect of the dilution temperature on POA and SOA formation. The concentrations of the POA and the aged OA from experiments at $80^{\circ} \mathrm{C}$ were within the range of concentrations obtained from the same type of experiments with the sampling line and the dilution air at $150^{\circ} \mathrm{C}$.

The carbon dioxide $\left(\mathrm{CO}_{2}\right)$ concentration in the exhaust was measured with a $\mathrm{CO}_{2}$ analyzer (LI-7000, LI-COR Biosciences) before the ejector diluter and in the smog chamber to calculate the exhaust dilution ratio.

Depending on the organic concentration and the total aerosol concentration desired for an experiment, the flow used to fill the bag for total emission experiments was either $12 \mathrm{~L} / \mathrm{min}$ or $33 \mathrm{~L} / \mathrm{min}$, and the filling time ranged from 7 to $20 \mathrm{~min}$. For the vehicle equipped with both a DOC and DPF the flow used to fill the bag was about $33 \mathrm{~L} / \mathrm{min}$ and the filling time was $30-40 \mathrm{~min}$. For the experiments with only the gas phase $3 \mathrm{~L} / \mathrm{min}$ through the filter was used and the filling time was $1 \mathrm{~h}$. After injection, 5-10 min were allowed for homogenization and mixing of the exhaust in the bag. Following the mixing, instruments sampled for approximately $1 \mathrm{~h}$ to characterize the primary emissions.

Prior to switching on the lights, ozone $\left(\mathrm{O}_{3}\right)$ was added to the exhaust in the chamber, while propene $\left(\mathrm{C}_{3} \mathrm{H}_{6}\right)$ was added after lights on. During preliminary experiments, photochemistry and subsequent SOA production was suppressed due to the high concentration of nitrogen monoxide (NO) present in the exhaust. Therefore, ozone was added to fully titrate the $\mathrm{NO}$ to nitrogen dioxide $\left(\mathrm{NO}_{2}\right)$, and propene was introduced to increase the $\mathrm{VOC} / \mathrm{NO}_{\mathrm{x}}$ ratio. The addition of propene was adjusted such that a propene to $\mathrm{NO}_{\mathrm{x}}$ ratio of $4: 1$ was obtained. Propene has often been added in SOA experiments as a photochemical initiator and to raise $\mathrm{OH}$ levels, and is not considered to be a relevant SOA precursor (Odum et al., 1996; Cocker et al., 2001) and may even reduce the SOA yield (Song et al., 2007).

After each experiment the smog chamber was cleaned by adding several ppm of ozone for $2-3 \mathrm{~h}$ and then purging it with zero air for at least $24 \mathrm{~h}$ before the next experiment. Before each experiment the chamber was checked for zero particle level with a condensation particle counter.

Blank experiments were performed once every $2-3$ weeks to check the effectiveness of the cleaning procedure and to make sure that the produced OA during the experiments was not significantly influenced by background impurities. The average OA concentration produced during blank experiments was $\sim 1 \mu \mathrm{g} / \mathrm{m}^{3}$ after $5 \mathrm{~h}$ (no wall loss correction).

In this paper we present results from 20 experiments. Table 1 describes the type of experiments performed, the operating conditions of the cars during the filling period, and the relevant initial conditions for the experiments. The total dilution ratios of the exhaust in the chamber are also reported in Table 1. The terms "cold idle" and "warm idle" refer to a cold engine start including idle mode and to exhaust from a warm engine at idle mode, respectively. 


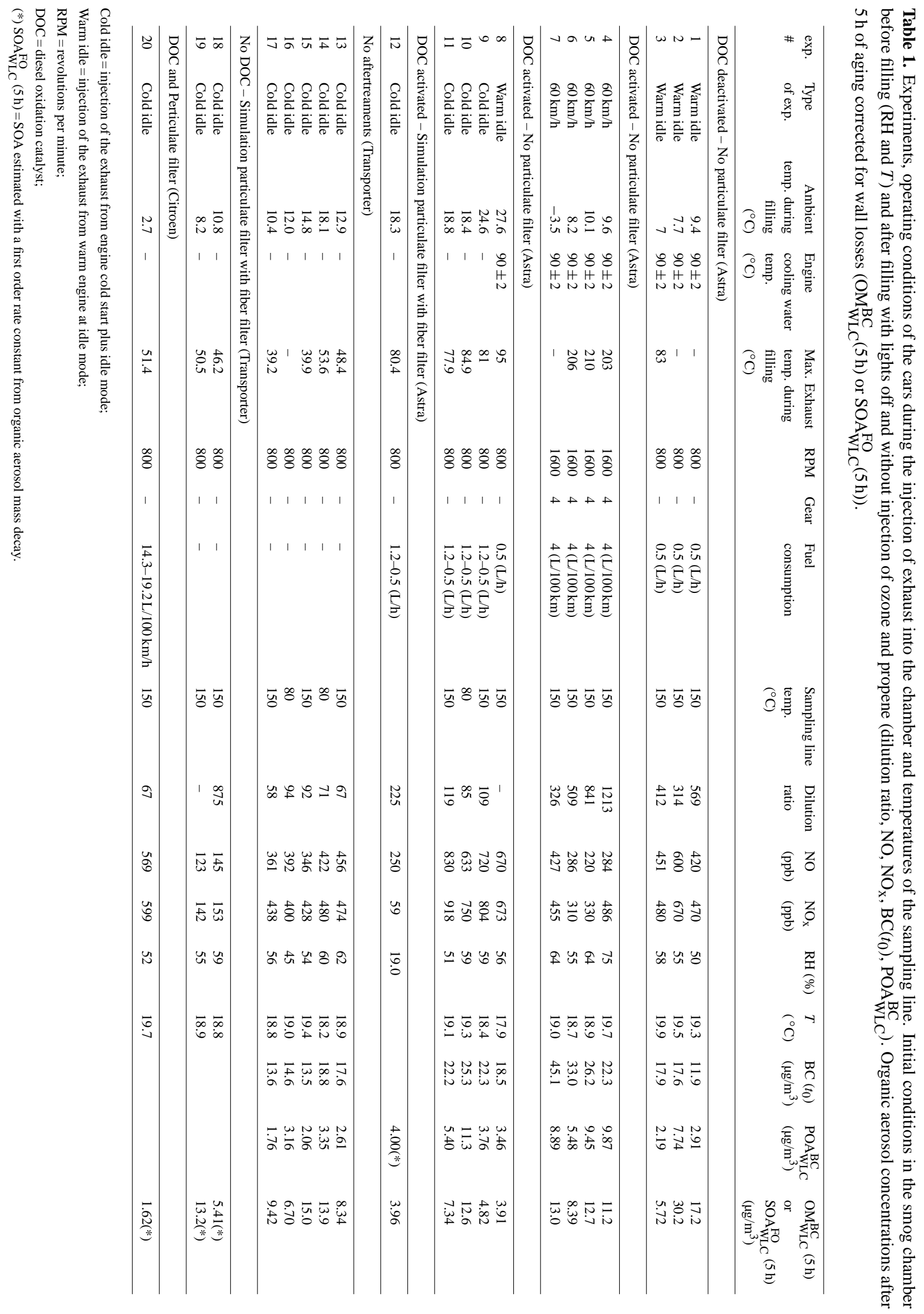




\subsection{Vehicle descriptions}

Three different commonly used passenger vehicles were used for our smog chamber experiments:

1. A EURO 2 Volkswagen Transporter TDI Syncro from December 2000, with a mileage of $109000 \mathrm{~km}$ not equipped with emission abatement devices. This vehicle will be referred to as "Transporter" throughout the manuscript.

2. A EURO 3 Opel Astra 2.0 DTI from February 2002, with a mileage of $45000 \mathrm{~km}$ equipped with a DOC. This vehicle will be referred to as "Astra" throughout the manuscript.

3. A EURO 3 Citroen C5 2.2 HDI from June 2001, with a mileage of $107000 \mathrm{~km}$ equipped with a diesel oxidation catalyst and a particulate filter (FAP 130 PS). The particulate filter of the Citroen was replaced before the experiments when the car had a mileage of $103000 \mathrm{~km}$. This vehicle will be referred to as "Citroen" throughout the manuscript. Only one smog chamber experiment was performed with this vehicle.

Prior to experiments, the Astra was driven on a flat road to assess the engine parameters such as revolutions per minute (RPM), fuel consumption and water temperature at different speeds. Those values were then used to simulate a $60 \mathrm{~km} / \mathrm{h}$ speed with this car at the smog chamber. To accomplish this, the front of the car was lifted, placed on blocks and the front wheels removed. The load and speed conditions of $60 \mathrm{~km} / \mathrm{h}$ were reproduced as follows: the brake line pressure was controlled using a pressurized gas bottle and the accelerator pedal was pressed until the fuel consumption was $4 \mathrm{~L} / 100 \mathrm{~km}$ at a virtual speed of $60 \mathrm{~km} / \mathrm{h}$. In this way an engine load similar to real driving conditions was achieved.

\subsection{Instrumentation}

\subsubsection{High Resolution Time-of-Flight Aerosol Mass Spectrometer (HR-ToF-AMS)}

The aerosol mass spectrometer (AMS) provides an averaged mass spectrum (MS) and the size-resolved non-refractory chemical characterization for an ensemble of submicron aerosol particles $\left(\mathrm{PM}_{1}\right)$ with a typical time resolution of seconds. A detailed description of the HR-ToF-AMS is reported elsewhere (DeCarlo et al., 2006), however a brief description is given here. Particles are introduced into the instrument via an aerodynamic lens focusing the particles into a tight beam. The focused particle beam is then directed into differentially pumped chambers under vacuum and towards a tungsten heater in the ionization region of the instrument. In the ionization region, particles impact on the $600{ }^{\circ} \mathrm{C}$ heater and non-refractory species are vaporized and the resulting gas phase plume is ionized with electron ionization $(70 \mathrm{eV})$.
Ions are then directed into the ToF mass spectrometer. The AMS inlet system shows $100 \%$ transmission efficiency to the detector for particles in the vacuum aerodynamic diameter range $70-500 \mathrm{~nm}$ and substantial transmission for particles in the $30-70 \mathrm{~nm}$ and $500 \mathrm{~nm}-1.5 \mu \mathrm{m}$ ranges for spherical particles (Liu et al., 2007). For non-spherical particles, the vacuum aerodynamic diameter is correlated to the volume equivalent diameter by the particle density, the standard density and the dynamic shape factor (DeCarlo et al., 2004).

The high mass resolution of the ToF mass spectrometer allows for the quantification of different ions contributing to a nominal $\mathrm{m} / \mathrm{z}$. The ability to distinguish these ions, allows for atomic ratios to be determined (e.g. $\mathrm{O} / \mathrm{C}, \mathrm{H} / \mathrm{C}$ atomic ratios) as well as the organic mass to organic carbon $(\mathrm{OM} / \mathrm{OC})$ ratio (Aiken et al., 2007, 2008). The detected ions can also be grouped into different inorganic and organic classes $\left(\mathrm{C}_{x} \mathrm{H}_{y}\right.$, $\mathrm{C}_{\mathrm{x}} \mathrm{H}_{\mathrm{y}} \mathrm{O}_{\mathrm{z}}, \mathrm{S}_{\mathrm{x}} \mathrm{O}_{\mathrm{y}}, \mathrm{N}_{\mathrm{x}} \mathrm{O}_{\mathrm{y}}$, etc.) on the basis of the atomic composition for each ion (DeCarlo et al., 2006); in this paper we focused on the 4 organic classes present: $\mathrm{CH}, \mathrm{CHO}$ (includes also fragments with only $\mathrm{C}$ and $\mathrm{O}$ ), $\mathrm{CHN}$, and $\mathrm{CHON}$.

AMS data can be used to identify different organic aerosol classes, such as hydrocarbon-like (HOA) and oxidized organic aerosols (OOA), which have different mass spectral signatures (Zhang et al., 2005b; Lanz et al., 2007).

Data analysis was performed in Igor Pro 6.03A (Wavemetrics, Lake Oswego, OR) using the ToFAMS Analysis Toolkit Squirrel v.1.44 and the ToF-AMS HR Analysis Toolkit PIKAv.1.04 (http: //cires.colorado.edu/jimenez-group/ToFAMSResources/

ToFSoftware/index.html). For the elemental analysis the data were analyzed based on the method described in Aiken et al. $(2007,2008)$.

In order to keep the AMS operating in optimal conditions, several checks and calibrations were performed before the beginning of every campaign and before each experiment. The flow calibration, the servo position check, the lens alignment and the size calibration were performed at the beginning of each campaign, while the ionization efficiency (IE) calibration was performed every week, the baseline, the $\mathrm{m} / \mathrm{z}$ and single ion calibrations were performed before each experiment (more details about the basic principle of each calibration can be found in http://cires.colorado.edu/jimenez-group/ wiki/index.php/Field_Data_Analysis_Guide and http://cires.colorado.edu/jimenez-group/QAMSResources/ Docs/AMS_manual_latest.pdf). The averaging time was 2 min in $\mathrm{V}$ mode or $\mathrm{W}$ mode, and in $\mathrm{V}$ mode the AMS alternated between MS mode and PToF mode every $10 \mathrm{~s}$.

The AMS fragmentation table (Allan et al., 2004) was modified to account for the contribution of the gas phase species to $m / z$ 16-20, 29, and 44. Gas-phase corrections were made by analyzing HEPA filtered air from the smog chamber after filling. Additionally, the organic contribution to $\mathrm{m} / \mathrm{z}$ $28\left(\mathrm{CO}^{+}\right)$and to $\mathrm{m} / z 18\left(\mathrm{H}_{2} \mathrm{O}^{+}\right)$were estimated to be $100 \%$ and $22.5 \%$ of the $\mathrm{CO}_{2}^{+}(\mathrm{m} / \mathrm{z} 44)$ signal, respectively, and the 
contributions to $\mathrm{m} / \mathrm{z} 17$ and $\mathrm{m} / \mathrm{z} 16$ were set to $25 \%$ and $4 \%$ of the signal at $m / z 18$ as suggested by Aiken et al. (2008). Only organic ions $\left(\mathrm{C}_{3} \mathrm{H}_{3}^{+}\right)$contributed to the difference mass spectrum at $\mathrm{m} / \mathrm{z} 39$ in these experiments in contrast to other aerosol types where potassium can be significant at $m / z 39$.

A particle collection efficiency (CE) of unity was assumed to estimate the non-refractory aerosol mass concentration. The CE of solid particles coated with liquid organics depends on the thickness of the coating (Matthew et al., 2008). For flame generated soot from propene a CE between about $90 \%$ and $95 \%$ was estimated (Slowik et al., 2004). The high fraction of black carbon in the primary particles $(\mathrm{OM} / \mathrm{BC}=0.11-$ 0.46) did not allow us to estimate the $\mathrm{CE}$ with confidence by mass closure with co-located instruments (MAAP and TEOM).

\subsubsection{Aethalometer}

The Aethalometer (AE31, Magee Scientific Company, Berkeley, CA) collects aerosols on a quartz filter and simultaneously measures the attenuation of light through the filter at various wavelengths. The attenuation coefficients at a wavelength of $\lambda=880 \mathrm{~nm}$ were used for the BC mass calculation with the Aethalometer. $\mathrm{BC}$ concentrations were calculated using a mass specific attenuation cross section of $16.6 \mathrm{~m}^{2} / \mathrm{g}$ (particles plus filter effects) and were empirically corrected for the shadowing effect (Weingartner et al., 2003). A double exponential fit was applied to smooth the BC data and account for wall loss correction calculations.

\subsubsection{Multi Angle Absorption Photometer (MAAP)}

The Multi Angle Absorption Photometer (MAAP, Model 5012, Thermo) measures the BC content of the aerosols simultaneously measuring the optical absorption and scattering of light by the particles collected on a glass fiber filter. A mass specific absorption cross section of $6.6 \mathrm{~m}^{2} / \mathrm{g}$ at $\lambda=630 \mathrm{~nm}$ (particles only) is used by the MAAP to convert the absorption measurement into a BC mass concentration. The MAAP was operated with a flow rate of $4 \mathrm{~L} / \mathrm{min}$. A double exponential fit was applied to smooth the BC data and account for wall loss correction calculations.

\subsubsection{Single Particle Soot Photometer (SP2)}

During later experiments the $\mathrm{BC}$ mass was also directly measured by a Single Particle Soot Photometer (SP2; Droplet Measurement Technologies; Stephens et al., 2003). The SP2 uses laser-induced incandescence for quantitative detection of the refractory BC mass in single particles independent of coatings with scattering materials (Moteki and Kondo, 2007; Slowik et al., 2007). The peak intensity of the detected incandescent light is proportional to the BC mass. Size-selected fullerene soot (Alfa Aesar), Aquadag (Acheson), and glassy carbon (Alfa Aesar, type 2) were used to calibrate the instrument's response curve. A minor part of the $\mathrm{BC}$ mass size distribution of diesel exhaust fell below the lower detection limit of the SP2 (1.4 fg BC corresponding to a black carbon effective diameter of $\sim 115 \mathrm{~nm}$ ). The $\mathrm{BC}$ mass below the cut was accounted for by fitting a lognormal distribution to the measured mass size distribution and integrating its area below the lower detection limit.

\subsubsection{Tapered Element Oscillating Microbalance (TEOM)}

Continuous real time measurements of particulate mass $\left(\mathrm{PM}_{10}\right)$ were performed with a tapered element oscillating microbalance (TEOM, Series 1400a, Thermo Scientific). Particulate mass is determined by measuring the change in the frequency of oscillation of the filter with increasing particulate loading. The PM mass was continuously determined via this method (every $3 \mathrm{~s}$ ). Ten-point smoothing was applied to the three-second data to reduce the measurement noise.

\subsubsection{Gas-phase instruments}

The following instruments were used to characterize the gas-phase: A Monitor Labs model ML9841A chemiluminescence $\mathrm{NO}_{\mathrm{x}}$ analyzer was used to measure $\mathrm{NO}$ and $\mathrm{NO}_{\mathrm{x}}$ $\left(\mathrm{NO}+\mathrm{NO}_{2}\right)$ (Paulsen et al., 2005), ozone was measured with an ozone analyzer Model 8810 (Monitor Labs Inc.) (Paulsen et al., 2005), $\mathrm{CO}_{2}$ was measured with a differential, non-dispersive, infrared (NDIR) gas analyzer (LI-7000, LI-COR Biosciences) and, the gas-phase total hydrocarbon (THC) concentration was measured with a FID Model VE 7 (J.U.M. Engineering).

\subsection{Deactivation of diesel oxidation catalyst}

The catalytic performance of a DOC can gradually worsen throughout the vehicle's lifetime and the DOC aging (or deactivation) can be chemical, physical and thermal. The interaction of sulfur dioxide $\left(\mathrm{SO}_{2}\right)$ present in the exhaust gas with the DOC can be physical and chemical and both processes can be reversible (Kozak and Jerzy, 2005; Andersson et al., 2007; Winkler et al., 2010; P. Dimopoulos, EMPA, personal communication, 2009).

The Astra used during the smog chamber experiments is a second-hand car from 2002 and was purchased by PSI at the end of 2007. Although we cannot conclusively demonstrate that the DOC was deactivated or poorly functioning, it is likely that during the first three experiments (\#1-3 in Table 1), this was the case. Evidence for this hypothesis involves the low total mileage of the vehicle upon purchase, implying predominantly urban driving where the exhaust temperatures stay relatively low. Additionally, test bench measurements with this vehicle at the European Joint Research Center (JRC) in Ispra, Italy (Chirico et al., 2010a; Giechaskiel et al., 2010), showed that at speeds lower than $140 \mathrm{~km} / \mathrm{h}$ the constituents of the particulate matter were BC 
and organic aerosols, while at $140 \mathrm{~km} / \mathrm{h}$ (including the acceleration from $120 \mathrm{~km} / \mathrm{h}$ to $140 \mathrm{~km} / \mathrm{h}$ ) $16 \pm 6 \%$ of the particulate matter measured was made of sulfates (Fig. S1 in the Supplement) which likely originated from the high temperature oxidation of the adsorbed $\mathrm{SO}_{2}$ to $\mathrm{SO}_{3}$ on the DOC with subsequent release of sulfate species. These sulfates are interpreted to stem from the catalyst as the fuel used had a sulfur fuel content of less than $50 \mathrm{ppm}$. After the first 3 experiments, the car was used under conditions simulating $60 \mathrm{~km} / \mathrm{h}$, and was driven several times on highways and across the Alps with high load and high temperature exhaust. In addition it was used in the aforementioned test bench measurements with speeds up to $140 \mathrm{~km} / \mathrm{h}$. Under these conditions, we hypothesize that by removal of the adsorbed sulfur compounds the DOC was regenerated and performance improved (P. Dimopoulos, EMPA, personal communication, 2009).

\subsection{Comparison of $\mathrm{BC}$ measurements with Aethalometer and MAAP}

During the first 2 experiments only the Aethalometer was used to measure $\mathrm{BC}$ while for the remaining experiments the MAAP and the Aethalometer were used together. The total mass measured during five experiments by the TEOM (experiment \#8,10,11, 13 and 14) was compared to the mass obtained by the sum of BC mass (Aethalometer or MAAP) and the organic mass (AMS). The total mass given by the MAAP plus the AMS showed a better agreement with the total mass measured by the TEOM for all experiments. The BC measurements from the Aethalometer, before lights on, were by a factor of $1.46 \pm 0.05$ higher than the $\mathrm{BC}$ measurements with the MAAP. This factor was then used to scale down the $\mathrm{BC}$ concentration derived from the Aethalometer measurements in the experiments when the MAAP was not cosampling. Filter changes indicated that both instruments had a filter loading dependent behavior. An example experiment with the BC concentration from the Aethalometer, MAAP, and SP2 measuring simultaneously is shown in Fig. S2 of the Supplement.

\section{Results and discussions}

\subsection{Direct on-line measurements of the primary emissions}

The emission factors (EF) expressed in $\mathrm{g} / \mathrm{kg}$ of burned fuel of BC, POA and gas-phase THC were estimated from direct measurements of the exhaust of the Transporter and the Astra with activated DOC (Fig. $\mathrm{S} 3$ in the Supplement). $\mathrm{CO}_{2}$, black carbon (MAAP), THC and organic aerosol were measured directly from the sampling line after the dilution stage at low dilution ratios of $\sim 1: 7$. The emission factors for various species were estimated in the following way:

$\mathrm{EF}(x)=10^{3}\left[x / \mathrm{CO}_{2}\right] w_{\mathrm{d}}$ where, $x$ is the concentration of $\mathrm{BC}$, POA or THC in $\mu \mathrm{g} / \mathrm{m}^{3}$, the carbon dioxide concentration, $\mathrm{CO}_{2}$, is expressed in $\mu \mathrm{gC} / \mathrm{m}^{3}$, and $w_{\mathrm{d}}$ is the mass fraction of carbon in the diesel fuel (0.87) (Phuleria et al., 2006). This assumes that nearly all of the fuel carbon is emitted as $\mathrm{CO}_{2}$. A comparison with the THC measurement shows that the highest THC contribution was $\sim 1.5 \%$ of the $\mathrm{CO}_{2}$ signal for the Transporter (no DOC or DPF). Note that the THC measurement includes contributions from e.g. lubricating oil, and not just fuel contributions, so $1.5 \%$ is an upper limit of THC contributions from fuel alone. Figure $\mathrm{S} 3$ shows that the $\mathrm{EF}(\mathrm{THC})$ is on average $\sim 5$ times higher for the Transporter than for the Astra, which is assumed to be mainly due to the presence of the DOC in the latter.

The time-weighted average $\mathrm{EF}(\mathrm{POA})$, from the first 20 min of measurement after the engine start (cold start included), was $0.99 \mathrm{~g} / \mathrm{kg}$ fuel and $1.2 \mathrm{~g} / \mathrm{kg}$ fuel for the Astra and the Transporter, respectively. These values were 7 (Astra, cold idle) and 15 (Transporter) times higher than values measured during smog chamber experiments. This difference can be explained by a lower dilution ratio (1:7) of the exhaust resulting in enhanced partitioning of SVOCs during these tests compared to the smog chamber experiments with much higher dilution ratios (Robinson et al., 2007). Additionally, the $\mathrm{EF}(\mathrm{BC})$ for the first $20 \mathrm{~min}$ of measurements at the sampling line $(1.2 \mathrm{~g} / \mathrm{kg}$ fuel $)$ was higher than the values estimated at the smog chamber. This is potentially a measurement artifact and is due to a larger fraction of condensed organic material at low dilution ratios enhancing the $\mathrm{BC}$ mass absorption efficiency and artificially increasing the estimated $\mathrm{BC}$ mass from the absorption measurement (Shiraiwa et al., 2010; Schnaiter et al., 2005).

\subsection{Smog chamber experiments}

\subsubsection{Primary organic mass to black carbon mass ratios}

The average organic matter to black carbon mass ratios $(\mathrm{OM} / \mathrm{BC})$ of the primary emissions from all experiments, measured from the smog chamber, were $0.28 \pm 0.15$ for a final dilution ratio between 60 and 1200 . For the experiments at idle conditions the average $\mathrm{OM} / \mathrm{BC}$ ratio was $0.23 \pm 0.10$, while for the experiments at $60 \mathrm{~km} / \mathrm{h}$ the ratio was $0.43 \pm 0.17$. The $\mathrm{OM} / \mathrm{BC}$ ratio for the Transporter (cold idle) was smaller $(0.17 \pm 0.03)$ than for the Astra $(0.27 \pm 0.11$, cold and warm idle). No significant variations were observed for the Astra comparing cold idle with warm idle. The average smog chamber OM/BC ratios for the Astra were lower by a factor of three compared to the value of 0.82 obtained from the on-line measurements of the exhaust of the Astra with a lower dilution ratio than smog chamber experiments (Sect. 3.1).

Low $\mathrm{OM} / \mathrm{BC}$ values were also measured for the Astra at the same conditions (idle and $60 \mathrm{~km} / \mathrm{h}$ ), and for other diesel vehicles, at the test bench facility of the JRC (Chirico et al., 
2010a). The OM/BC ratio can be vehicle specific (type of engine, temperatures, oxidation catalyst, etc) and it also depends on the dilution of the exhaust as already shown by Lipsky and Robinson (2006). These results are consistent with the measurements of other studies as well. Bosteels et al. (2006) found that the EC content of the PM measured from two diesel passenger cars with DOC from four different test cycles ranged from 79 to $92 \%$. Measurements made at Empa (Swiss Federal Laboratories for Materials Testing and Research) during vehicle chasing experiments of a different EURO 3 diesel car equipped with a DOC showed OM/BC ratios of 0.28 at $50 \mathrm{~km} / \mathrm{h}, 0.21$ at $80 \mathrm{~km} / \mathrm{h}, 0.3$ at $100 \mathrm{~km} / \mathrm{h}$, and 0.18 at $120 \mathrm{~km} / \mathrm{h}$ (Silke Weimer, EMPA, personal communication, 2008). These low values indicate that the primary exhaust aerosol of modern diesel vehicles consists mainly of BC with a low fraction of OM. In contrast, Shah et al. (2004) found much higher contribution of OC than EC at idle conditions for a number of heavy heavy-duty diesel trucks.

Using the high-resolution mass spectra and elemental analysis (Aiken et al., 2007, 2008), we determined the organic matter to organic carbon ratios $(\mathrm{OM} / \mathrm{OC})$ in our experiments (details in Sect. 3.2.3). The OM/OC values allow us to convert the $\mathrm{OM} / \mathrm{BC}$ ratios to more commonly found organic carbon to black carbon (OC/BC) values. For the experiments presented here we determined $\mathrm{OM} / \mathrm{OC}$ values to be: 1.26 (warm idle, Astra, experiment \#8), 1.33 (warm idle, Astra, DOC deactivated, average), 1.28 (60 km/h, Astra, average), 1.40 (cold idle, Transporter, average). This yields an $\mathrm{OC} / \mathrm{BC}$ ratio between 0.12 (cold idle, Transporter, average) and $0.33(60 \mathrm{~km} / \mathrm{h}$, Astra, average).

\subsubsection{SOA formation from diesel vehicles and methods for wall loss correction}

Photochemical aging experiments with the Transporter exhibited substantial SOA production. In Fig. 2a the temporal evolutions of $\mathrm{OM}$ and $\mathrm{BC}$ are shown for a characteristic experiment with the Transporter (no exhaust aftertreatment devices, exp. \#15). The $\mathrm{OM}$ and $\mathrm{BC}$ concentrations at time zero were $1.70 \mu \mathrm{g} / \mathrm{m}^{3}$ and $12.4 \mu \mathrm{g} / \mathrm{m}^{3}$, respectively. With lights on, photooxidation in the smog chamber produced additional $\mathrm{OM}$ mass, and after $3.3 \mathrm{~h}$ of aging the maximum OM concentration of $10.4 \mu \mathrm{g} / \mathrm{m}^{3}$ was measured (without wall loss corrections). The temporal evolutions of $\mathrm{OM} / \mathrm{BC}$ ratios are shown in Fig. $2 b$ for all experiments with the same vehicle. At time zero, the primary $\mathrm{OM} / \mathrm{BC}$ ratio was $0.11-0.21$ and after $5 \mathrm{~h}$ of aging and addition of SOA the ratio increased to $0.44-1.12$.

\section{Wall loss correction using black carbon measurements}

During smog chamber experiments, particles are lost to the walls. Particulate losses were quantified by assuming that the aerosol was internally mixed, such that $\mathrm{OM}$ and $\mathrm{BC}$ have the same wall-loss rates, and $\mathrm{BC}$ can be used as tracer for

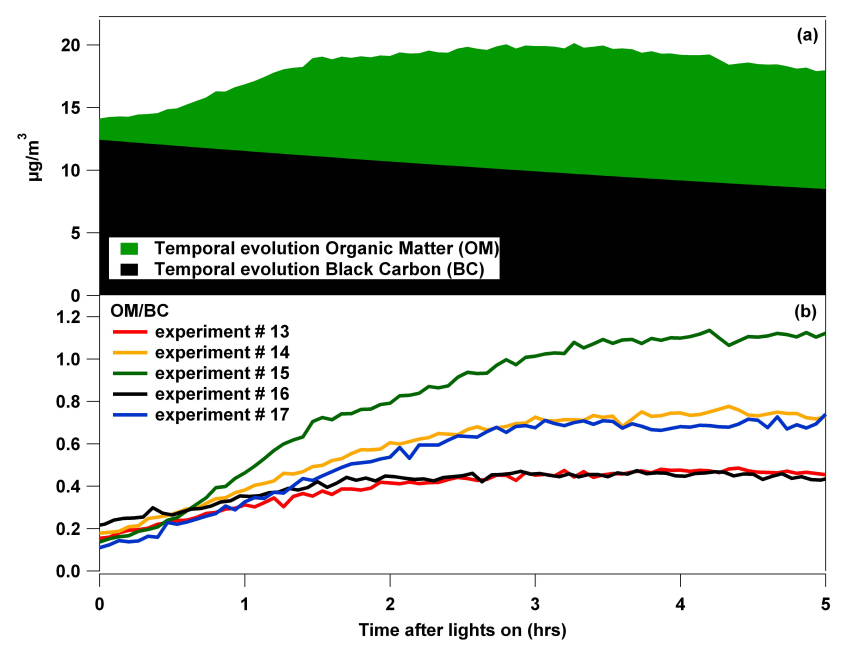

Fig. 2. (a) Temporal evolution of the organic matter (OM) and black carbon (BC) from a characteristic smog chamber experiment with substantial SOA production (exp. \#15, a) and, (b) temporal evolution of $\mathrm{OM} / \mathrm{BC}$ ratios from experiments with the diesel vehicles without aftertreatments.

chamber wall loss (Grieshop et al., 2009). Previous studies have shown that filter based absorption measurements used to infer BC mass concentration can be biased to higher values due to an increasing mass absorption efficiency (MAE) with an increasing layer of scattering organic material around the absorbing core of BC (Shiraiwa et al., 2010; Schnaiter et al., 2005). The use of a constant MAE when realistically it is likely increasing due to SOA addition will result in an underestimation of wall-loss corrected SOA (SOAWLC) if using MAAP or Aethalometer inferred BC as a wall loss tracer. The uncertainty of this effect will be discussed later in more detail. The concentration of OM corrected for wall losses $\left(\mathrm{OM}_{\mathrm{WLC}}^{\mathrm{BC}}\right)$ was estimated in the following way:

$\mathrm{OM}_{\mathrm{WLC}}^{\mathrm{BC}}=\mathrm{OM}_{\text {Meas }}(t) \times\left[\mathrm{BC}\left(t_{0}\right) / \mathrm{BC}(t)\right]$,

where $\mathrm{BC}\left(t_{0}\right)$ and $\mathrm{BC}(t)$ are the $\mathrm{BC}$ concentrations measured in the smog chamber before lights were turned on and measured at time $t$, respectively, and $\mathrm{OM}_{\text {Meas }}(t)$ is the organic aerosol mass measured at time $t$. The assumption is that newly formed low and semi-volatile species also condense/partition to those particles that were lost to the wall. The wall-loss corrected $\mathrm{POA}_{\mathrm{WLC}}^{\mathrm{BC}}$ can be similarly calculated using Eq. (2), by substituting OM by POA. The wall-loss corrected concentrations of organic aerosol for the experiments with the Transporter are shown in Fig. 3a. The initial $\mathrm{OM}_{\mathrm{WLC}}^{\mathrm{BC}}$ concentration, corresponding to $\mathrm{POA}_{\mathrm{WLC}}^{\mathrm{BC}}$, was $1.76-3.35 \mu \mathrm{g} / \mathrm{m}^{3}$ with an average value of $2.6 \pm 0.6 \mu \mathrm{g} / \mathrm{m}^{3}$. At time zero, the lights were turned on and photochemical reactions initiated the production of SOA. In experiments 13-17 with the Transporter, after approximately $3.5 \mathrm{~h}$ a plateau of $\mathrm{OM}_{\mathrm{WLC}}^{\mathrm{BC}}$ was reached and ranged between 6.70 and $15.0 \mu \mathrm{g} / \mathrm{m}^{3}$ with an average value of $10.7 \pm 3.2 \mu \mathrm{g} / \mathrm{m}^{3}$. 


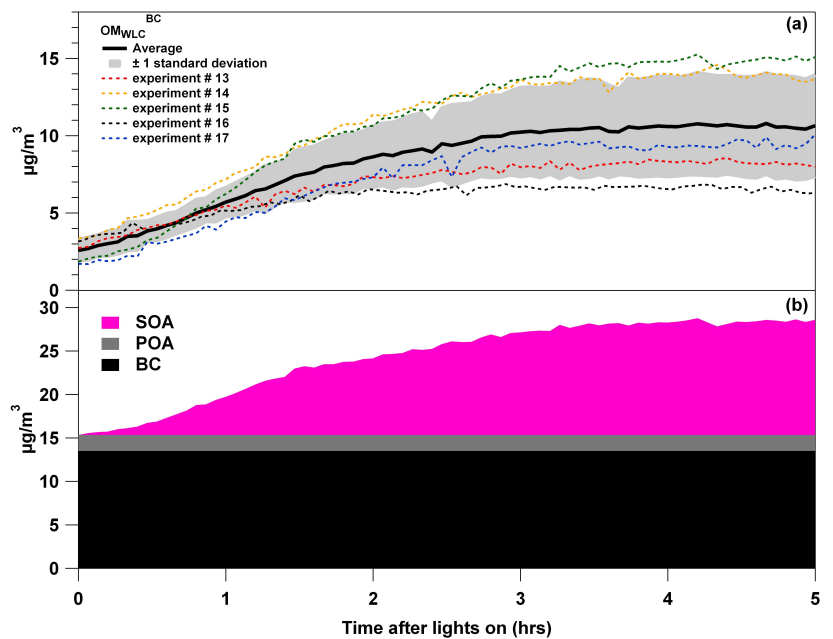

Fig. 3. (a) Temporal evolution of the wall-loss corrected organic aerosol mass concentration $\left(\mathrm{OM}_{\mathrm{WLC}}^{\mathrm{BC}}\right)$ for the diesel vehicle without aftertreatments and, (b) temporal evolution of $\mathrm{OM}_{\mathrm{WLC}}^{\mathrm{BC}}$ for the same experiment in Fig. 2a, b: total organics is the sum of the pink and gray areas with the gray area equal to POA, assuming a constant POA to $\mathrm{BC}$ ratio for the full experiment. The pink area is the estimated SOA from subtracting the POA from the total OA.

Figure $3 \mathrm{~b}$ shows the same experiment of Fig. 2a after the wall-loss correction has been applied. Here we assume that the MAE is not altered significantly by the addition of SOA and that the POA/BC ratio is constant over the course of the experiment. The latter assumption will be discussed in more detail in the section "Ion enhancement ratios (IER): Ion enhancement ratios (IER) of selected ions". SOA is calculated from the subtraction of $\mathrm{POA}_{\mathrm{WLC}}^{\mathrm{BC}}$ from the total $\mathrm{OM}_{\mathrm{WLC}}^{\mathrm{BC}}$, and is shown in pink. The percent contribution of SOA to the total organic mass can be estimated for each point in time by:

$\% \mathrm{SOA}(t)=\left[1-\left(\mathrm{POA}_{\mathrm{WLC}}^{\mathrm{BC}}(\mathrm{t}) / \mathrm{OM}_{\mathrm{WLC}}^{\mathrm{BC}}(\mathrm{t})\right] \times 100 \%\right.$.

For the experiment in Fig. 3b, SOA is $86 \%$ of the total OM after $5 \mathrm{~h}$ of photooxidation.

\section{SOA calculation from $m / z 57$ and $\mathrm{C}_{4} \mathrm{H}_{9}^{+}$}

Previous studies have estimated the SOA formation during smog chamber experiments with a diesel power generator by subtracting the initial OM mass (POA) from the total $\mathrm{OM}$ at time $t$ in the following way (Sage et al., 2008):

$\mathrm{SOA}(t)=\mathrm{OM}(t)-\left[\left(\operatorname{Org} 57(t) / \operatorname{Org} 57\left(t_{0}\right)\right) \times \mathrm{OM}\left(t_{0}\right)\right]$,

where $\mathrm{OM}(t)$ is the measured total OM concentration at time $t, \operatorname{Org} 57(t)$ is the organic mass signal at $\mathrm{m} / z .57$ at time $t$, $\operatorname{Org} 57\left(t_{0}\right)$ is the organic mass signal at $\mathrm{m} / \mathrm{z} 57$ at time zero, and $\mathrm{OM}\left(t_{0}\right)$ is the $\mathrm{OM}$ concentration at time zero, before lights on.

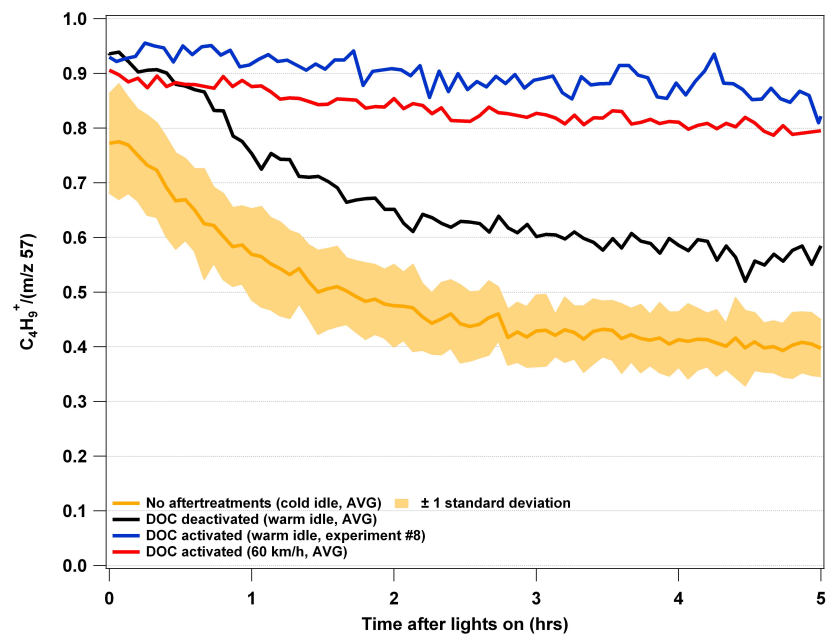

Fig. 4. Temporal evolution of the fraction of $\mathrm{C}_{4} \mathrm{H}_{9}^{+}$to total $\mathrm{m} / z 57$. The orange and blue lines are average values.

In general, $\mathrm{m} / \mathrm{z} 57$ is associated predominantly with primary species and typically comes from long-chain alkyl groups $\left(\mathrm{C}_{4} \mathrm{H}_{9}^{+}\right)$, which are an important functionality in diesel exhaust, and it is one of the dominant ions in the EI mass spectra of organic aerosols from diesel engines (Schauer et al., 1999; Canagaratna et al., 2004; Schneider et al., 2006; Weitkamp et al., 2007). The use of $m / z 57$ in Eq. (4) assumes that it is predominantly from primary species (in the form of $\mathrm{C}_{4} \mathrm{H}_{9}^{+}$) and the ratio of $\mathrm{m} / z, 57$ to POA stays constant during aging. However, oxygen containing ions, such as $\mathrm{C}_{3} \mathrm{H}_{5} \mathrm{O}^{+}$also can contribute significant mass to the signal $\mathrm{m} / \mathrm{z} 57$ (DeCarlo et al., 2006). The high resolution data for the experiments presented here show that this is indeed the case. Figure 4 presents the temporal contributions of $\mathrm{C}_{4} \mathrm{H}_{9}^{+}$ to the total $\mathrm{m} / \mathrm{z} 57$ signal. At the beginning of the experiments, $\mathrm{C}_{4} \mathrm{H}_{9}^{+}$was the major fraction of the signal at $m / z, 57$ (from $77 \%$ for the Transporter to 94\% for the Astra with deactivated DOC). After irradiation began, the relative fraction of the $\mathrm{C}_{3} \mathrm{H}_{5} \mathrm{O}^{+}$fragment at $\mathrm{m} / \mathrm{z} 57$ increased with time especially for those experiments with higher SOA production.

From this observation, it is clear that the use of Eq. (4) will overestimate the POA concentrations (by assigning all $\mathrm{m} / \mathrm{z} 57$ to primary species) and consequently underestimate the SOA production of these experiments. This is particularly true for the experiments with no or poorly functioning aftertreatment devices. For the Transporter (grey trace) and the Astra with deactivated DOC (blue trace) after $5 \mathrm{~h}$ of aging the contribution of $\mathrm{C}_{3} \mathrm{H}_{5} \mathrm{O}^{+}$to $\mathrm{m} / 2,57$ was around $60 \%$ and $41 \%$, respectively. For the Astra experiments at $60 \mathrm{~km} / \mathrm{h}$ (red trace) and the warm idle conditions with activated DOC (orange trace) the contribution was around $20 \%$. 


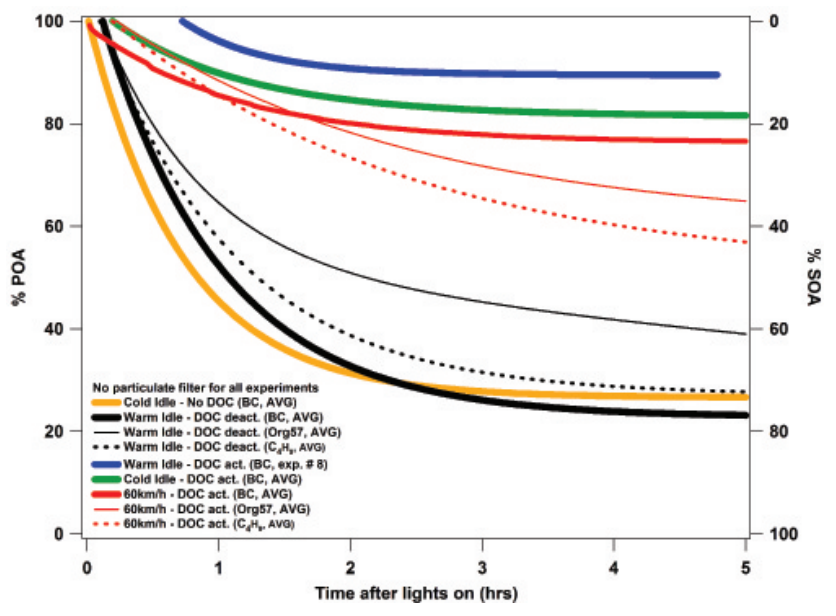

Fig. 5. Average POA and SOA contribution to total organic mass estimated using the black carbon assumption for wall loss correction (Eq. 2, thick solid lines), the $\mathrm{C}_{4} \mathrm{H}_{9}$ normalization method (Eq. 5 , thin solid lines) and the Org57 normalization method (Eq. 4, dashed lines).

A more appropriate way to calculate the SOA formation is done by substituting $\mathrm{m} / \mathrm{z} 57$ in Eq. (4) with the nonoxygenated fragment $\mathrm{C}_{4} \mathrm{H}_{9}^{+}$at $m / z, 57$ :

$\mathrm{SOA}(t)=\mathrm{OM}(t)-\left[\left(\mathrm{C}_{4} \mathrm{H}_{9}^{+}(t) / \mathrm{C}_{4} \mathrm{H}_{9}^{+}\left(t_{0}\right)\right) \times \mathrm{OM}\left(t_{0}\right)\right]$.

\section{Comparison of the methods for estimating SOA}

The relative contribution of SOA to the evolving organic mass estimated with Eq. (2) (BC WLC correction) is reported in Fig. 5 for all experiments. For the Transporter and the Astra with deactivated DOC the percentage of SOA estimated was similar and after $5 \mathrm{~h}$ of aging it was $77 \%$ and $73 \%$, respectively, while for the Astra with activated DOC the SOA estimated was only $11 \%$ (warm idle) and $18 \%$ (cold idle). This is an indication that the DOC efficiently oxidized a significant amount of gaseous organic species in the diesel exhaust, which would otherwise have contributed to the SOA formation. Indeed, this observation is very interesting and not completely clear because one might expect also a significant reduction of the organics contributing to POA in the catalyst. The dilution however is much smaller at this stage thus a significant fraction might still be "hidden" in the primary aerosol in the catalyst. The efficiency of the catalyst likely varies for organics with different functionality and the oxidation in general is changing overall the volatility distribution of the organics. One may hypothesize that the oxidation in the catalyst may lead either to oxidation/fragmentation of organics that would be part of POA without the DOC and/or to oxidation/functionalization of organics in the gas-phase adding to POA. These effects may compensate each other and we finally find a slightly enhanced $\mathrm{O} / \mathrm{C}$ ratio of POA with the DOC.
Experiments at $60 \mathrm{~km} / \mathrm{h}$ with the Astra yielded 23\% SOA after $5 \mathrm{~h}$, higher than the contribution of SOA during the warm and cold idle experiments with activated DOC. Measurements of the exhaust temperature at the tailpipe of the Astra, during the filling period, reached a maximum $\sim 80$ $90^{\circ} \mathrm{C}$ during idle experiments and a maximum of $210^{\circ} \mathrm{C}$ for the $60 \mathrm{~km} / \mathrm{h}$ experiments. This means that the temperature to efficiently remove organics $\left(\sim 200^{\circ} \mathrm{C}\right)$ in the DOC (Katare et al., 2007) was likely only reached during the $60 \mathrm{~km} / \mathrm{h}$ experiments. Thus, the higher SOA production at $60 \mathrm{~km} / \mathrm{h}$ compared to the experiments at idle mode could potentially be explained by a relatively higher emission of unburned or partially burned fuel, due to the higher fuel consumption at $60 \mathrm{~km} / \mathrm{h}$, even if the DOC had a better conversion efficiency.

The \%SOA estimation with the other two methods $\left(\mathrm{C}_{4} \mathrm{H}_{9}^{+}\right.$ and Org57 methods) are reported in Fig. 5 for two types of experiments that are close to the extremes and should bracket the results for all other experiments: one experiment where SOA production was high (warm idle, DOC deactivated) and one experiment where little SOA was produced $(60 \mathrm{~km} / \mathrm{h}$, DOC activated). At high SOA production, the average SOA estimation using $\mathrm{C}_{4} \mathrm{H}_{9}^{+}$(Eq. 5) after $5 \mathrm{~h}$ was $72 \%$ of the total $\mathrm{OM}$ which is similar to the average SOA value obtained for the same experiments with the BC method (77\%). On the other hand, for the $60 \mathrm{~km} / \mathrm{h}$ experiments the discrepancy between the two methods $\left(\mathrm{BC}\right.$ and $\mathrm{C}_{4} \mathrm{H}_{9}^{+}$) is more pronounced, with $23 \%$ versus $43 \%$. Using Org57 (Eq. 4) the average SOA estimated after $5 \mathrm{~h}$ was significantly lower than for the other 2 methods at $61 \%$ (idle) and in between the other methods for the $60 \mathrm{~km} / \mathrm{h}$ at $35 \%$. Using the $\mathrm{Org} 57$ and $\mathrm{C}_{4} \mathrm{H}_{9}^{+}$methods for the $60 \mathrm{~km} / \mathrm{h}$ experiments, the SOA was overestimated by $52 \%$ and $87 \%$, respectively.

\section{Ion enhancement ratios (IER)}

Ion enhancement ratios (IER) of selected ions from the POA mass spectrum were calculated to assess whether the chemical composition of POA changed with aging time. The method used is similar to the organic enhancement ratios given in Grieshop et al. (2009), but applied to individual ions rather than the bulk $\mathrm{OA}$ and is defined as:

$\operatorname{IER}=\left[\operatorname{Ion}(t) / \operatorname{Ion}\left(t_{0}\right)\right] /\left[\mathrm{BC}(t) / \mathrm{BC}\left(t_{0}\right)\right]$,

where $\operatorname{Ion}(t)$ and $\operatorname{Ion}\left(t_{0}\right)$ are the ion signals at time $t$ and at the time when the lights were turned on $\left(t_{0}\right)$, respectively.

The temporal evolutions of IERs for all the experiments with the Transporter are shown in Fig. 6 (calculated using the BC WLC correction method), while in Fig. S4 the temporal evolution of IERs for two characteristic experiments with the Astra (\#3, idle, deactivated DOC; \#7, $60 \mathrm{~km} / \mathrm{h}$ ) are reported. The different ions from the alkyl fragment series $\left(\mathrm{C}_{n} \mathrm{H}_{2 n+1}^{+}\right)$ had markedly different behaviors for experiments with high and low SOA production. The IER of $\mathrm{C}_{3} \mathrm{H}_{7}^{+}$increased to a maximum of $\sim 4$ for the experiment with higher SOA production (\#15), the IER of $\mathrm{C}_{4} \mathrm{H}_{9}^{+}$increased to a maximum 


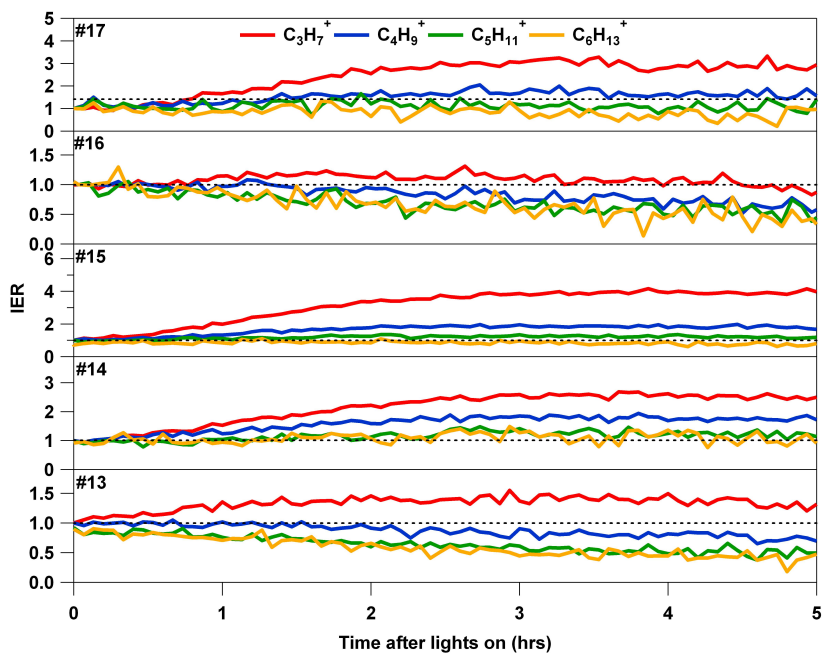

Fig. 6. Temporal evolution of the ion enhancement ratios of selected markers of primary organic aerosols.

of $\sim 2$ for three experiments (\#14, 15, and 17), the IER of $\mathrm{C}_{5} \mathrm{H}_{11}^{+}$was $\sim 1.4\left(\# 14,15\right.$, and 17), while the IER of $\mathrm{C}_{6} \mathrm{H}_{13}^{+}$ was almost stable around unity.

For two experiments the SOA formation was somewhat lower (\#13 and 16). These experiments showed an IER increase only for the $\mathrm{C}_{3} \mathrm{H}_{7}^{+}$ion (maximum $\sim 1.5$ ) and once $\mathrm{SOA}$ production ceased the ratio began to decrease with the continuing photochemistry. The $\mathrm{C}_{4} \mathrm{H}_{9}^{+}$IERs for these two experiments were nearly flat until $\sim 1.5 \mathrm{~h}$ since lights on and then began to decrease to values below unity. The IERs for $\mathrm{C}_{5} \mathrm{H}_{11}^{+}$and $\mathrm{C}_{6} \mathrm{H}_{13}^{+}$decreased from the beginning of the experiments while the smaller alkyl fragments sometimes first increased before eventually decreasing as well.

Thus, the use of a particular ion as a tracer for POA and subsequent spectral subtraction (Robinson et al., 2007; Sage et al., 2008) can lead to different results depending on the particular IER behavior. On the one hand, if the ion has an increasing IER (e.g. $\mathrm{C}_{4} \mathrm{H}_{9}^{+}$in experiments \#14, 15, and 17), then the use of this ion for normalization will overestimate the POA during the experiment. In spectral subtraction exercises $\left(\mathrm{MS}_{\mathrm{SOA}}=\mathrm{MS}_{\text {totalOA }}-\right.$ ionNormalizedMS $\left.\mathrm{MOA}_{\mathrm{PO}}\right)$ this will also "oversubtract" a primary component from the total mass spectrum, yielding a difference spectrum that is more oxidized than the "real" SOA mass spectra. On the other hand, if IERs decrease throughout an experiment (e.g. $\mathrm{C}_{4} \mathrm{H}_{9}^{+}$experiments \#13 and 16) then one can see that the primary OA is lost via the photochemical processes in the chamber. In this case the oxidized organic aerosol may not only include SOA but also oxidized primary species commonly called OPOA (Robinson et al., 2007; Baltensperger and Prevot, 2008; Sage et al., 2008). These observations indicate that the assumption of constant POA/BC and constant POA mass spectra do not hold true for these situations and are only rough approximations.
The difference in IERs for the alkyl ion series is due to the oxidative processing of the molecules of the OA. Oxidation of hydrocarbons with $\mathrm{OH}$ radicals creates several organic products with carbonyl and hydroxyl groups as well as shorter chains due to fragmentation (Atkinson and Arey, 2003). As photochemical aging in the smog chamber progresses, the concentration of long alkyl groups of SVOCs in the system decreases faster than the concentration of shorter alkyl chains. This is because the longer alkyl chains can, by the addition of a functional group (-OH or $\mathrm{O}$ ) still contain a shorter alkyl chain, but will have lost the longer unadulterated alkyl group. For all alkyl ion fragments the measured concentration in the AMS reflects a balance between the gain of SOA containing unoxidized alkyl chains through condensation and the loss. Loss processes can be either volatilization and subsequent reaction and/or heterogeneous chemistry.

With higher OA addition from photochemistry, IERs indicate that in general for the lighter ions $\left(\mathrm{C}_{3} \mathrm{H}_{7}^{+}\right.$and $\left.\mathrm{C}_{4} \mathrm{H}_{9}^{+}\right)$ the gain by condensation of new mass is greater than the loss by oxidation on the timescales of the chamber experiments (see Fig. S5 in the Supplement). For $\mathrm{C}_{5} \mathrm{H}_{11}^{+}$and $\mathrm{C}_{6} \mathrm{H}_{13}^{+}$the gain and loss processes are nearly balanced for percentages of SOA higher than $\sim 77 \%$, while for values lower than $68 \%$ the loss processes dominate.

As we have shown, SOA quantification with $\mathrm{C}_{4} \mathrm{H}_{9}^{+}$can be affected in either direction from the relative rates of the gain and loss processes that take place during the experiments. However, the use of this ion for wall loss corrections is still an improvement over the use of the total signal at $\mathrm{m} / \mathrm{z} 57$.

Lastly, it should again be mentioned that MAE can change for BC with coating of secondary material and this will result in an underestimation of SOA if BC is used as wall loss tracer. From the coincident measurements of the SP2 and the MAAP, we can estimate the magnitude of the change in the MAE. As the BC measurement with the SP2 is not affected by an organic coating an increase in the $\mathrm{BC}_{\mathrm{MAAP}} / \mathrm{BC}_{\mathrm{SP} 2}$ ratio with time would indicate that the condensation of secondary species enhances the MAE. Using a fixed MAE to calculate $\mathrm{BC}$ concentrations from the MAAP absorption measurement would then result in overestimated $\mathrm{BC}$ concentrations. After $5 \mathrm{~h}$ of aging the increase in the $\mathrm{BC}_{\mathrm{MAAP}} / \mathrm{BC}_{\mathrm{SP} 2}$ ratio was less than 10\% (average value from experiment \#13 and 14) and we consider the coating effect on the $\mathrm{BC}$ measurement by the MAAP to be small. For this reason in the remainder of the paper we will use the BC method to correct for wall losses when primary emissions are present in the chamber.

\section{First order wall loss correction for gas phase only experiments}

To account for wall losses in experiments with only the gas phase of diesel exhaust (see Sect. 3.2.5) another method was required. A first order rate constant for diffusional wall losses was estimated from the organic aerosol mass decay 

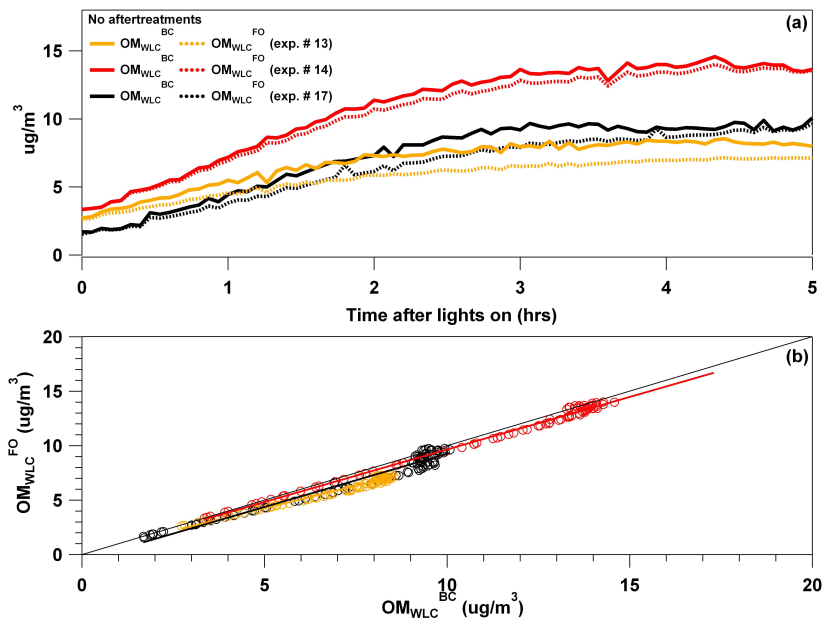

Fig. 7. Temporal evolution of the wall-loss corrected OM with $\mathrm{BC}$ $\left(\mathrm{OM}_{\mathrm{WLC}}^{\mathrm{BC}}\right)$ and with the first order rate constant from the OM decay before lights on $\left(\mathrm{OM}_{\mathrm{WLC}}^{\mathrm{FO}}\right)$ (a) and scatter plot with orthogonal regressions (b).

at the end of the gas-phase only experiments, when the SOA production rate was considered negligible compared to the mass loss rate by diffusion.

The first order wall loss correction was compared to the $\mathrm{WLC}_{B C}$ method for standard diesel experiments $(\mathrm{POA}+\mathrm{SOA})$. The agreement between the two methods is shown in Fig. 7a where the temporal evolution of wall-loss corrected $\mathrm{OM}$ using $\mathrm{BC}\left(\mathrm{WLC}^{\mathrm{BC}}\right)$ and using the first order mass decay ( $\mathrm{WLC}^{\mathrm{FO}}$ ) for 3 different experiments are reported. The methods are also compared as a scatter plot in Fig. 7b where the slopes from orthogonal distance regressions (with the intercepts forced to zero) range from 0.84 0.98 .

\subsubsection{Atomic ratios and $\mathrm{OM} / \mathrm{OC}$ ratio from fresh and aged diesel aerosols}

The high resolution data of the AMS allow for the determination of the atomic ratios of the OA (Aiken et al., 2007, 2008). Figure 8 shows the temporal evolutions of the $\mathrm{O} / \mathrm{C}$ and $\mathrm{H} / \mathrm{C}$ atomic ratios as well as the $\mathrm{OM} / \mathrm{OC}$ ratio. For primary emissions, before the initiation of photochemistry, the $\mathrm{H} / \mathrm{C}$ ratios had average values of 1.83 (all the experiments with the Astra) and 1.68 (all the experiments with the Transporter) while the average $\mathrm{O} / \mathrm{C}$ ratios had values of 0.097 and 0.190 for the Astra and the Transporter, respectively. Accordingly, the measured $\mathrm{OM} / \mathrm{OC}$ ratios for POA were relatively low, with 1.29 and 1.40 for the experiments with the Astra and the Transporter, respectively. The initial O/C ratios measured here are relatively close to the value of 0.03 for POA sampled from a diesel truck and the values of 0.060.10 obtained for the HOA factor from positive matrix factorization (PMF) of ground and aircraft data in Mexico City (Aiken et al., 2008; DeCarlo et al., 2010).

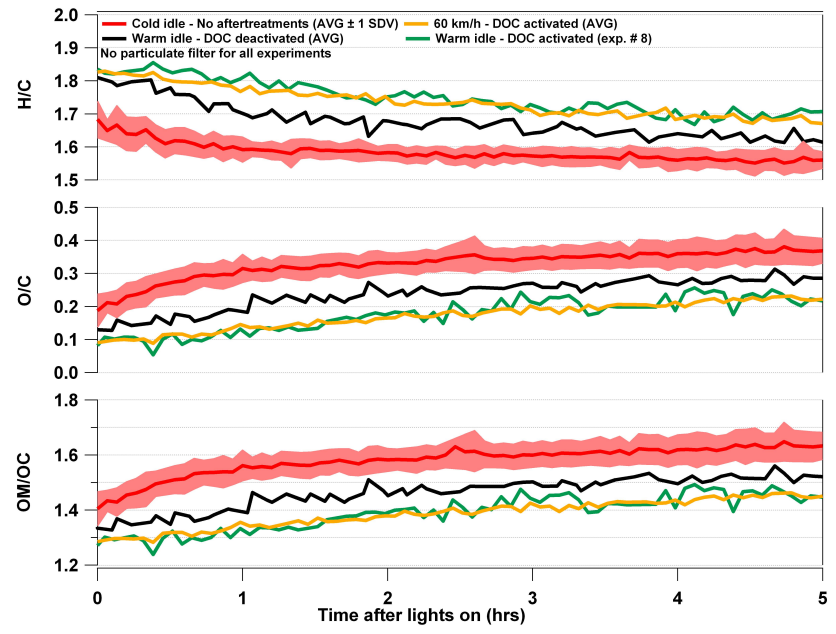

Fig. 8. Time series of average $\mathrm{O} / \mathrm{C}$ and $\mathrm{H} / \mathrm{C}$ atomic ratios and of average $\mathrm{OM} / \mathrm{OC}$ ratios. The shaded areas represent the average values \pm one standard deviation.

After $5 \mathrm{~h}$ of photochemical aging the average $\mathrm{H} / \mathrm{C}$ ratio decreased to 1.66 for the Astra and 1.57 for the Transporter, while the average $\mathrm{O} / \mathrm{C}$ ratio increased to 0.24 (Astra) and 0.37 (Transporter). In parallel, the OM/OC values increased to 1.47 (Astra) and 1.63 (Transporter) after $5 \mathrm{~h}$ of aging. The $\mathrm{O} / \mathrm{C}$ values of the diesel OA after $5 \mathrm{~h}$ of aging are in the range of values of the SV-OOA (Jimenez et al., 2009), which is consistent with SV-OOA typically being associated with fresh SOA. The higher O/C ratio in the POA from the Transporter compared to the Astra is likely due to the differences in the two engines (fuel consumption, temperature, etc). While the presence of a DOC may be thought to contribute to this difference, results from the mass spectral analysis (see next section) suggest that the processes in the DOC are not the most important factors influencing the $\mathrm{O} / \mathrm{C}$ ratio of the primary exhaust.

\subsubsection{Mass spectral analysis of organic aerosols from photooxidation experiments}

\section{Primary organic aerosol mass spectral analysis}

The organic fraction of diesel particles consists of a mixture of compounds from fuel and lubricating oil (some partially burned) and both show a characteristic fragmentation pattern in the mass spectrum. Engine type and load affect the relative contribution of fuel and lubrication oil to the resulting organic mass (Schneider et al., 2006). Diesel fuels contain a hydrocarbon mixture that ranges roughly from $\mathrm{C} 10$ to $\mathrm{C} 25$ with a boiling point between 280 and $360^{\circ} \mathrm{C}$, whereas lubricating oils mainly consists of hydrocarbon mixtures from $\mathrm{C} 14$ to $\mathrm{C} 45$ with boiling points between 400 and $550^{\circ} \mathrm{C}$ (Kweon et al., 2003 and references therein). In the following section, we use the high-resolution mass spectra to gain 
more chemical information about the 4 organic classes: $\mathrm{CH}$, $\mathrm{CHO}$ (also includes fragments with only $\mathrm{C}$ and $\mathrm{O}$ ), $\mathrm{CHN}$, and CHON.

Figure 9 shows the average normalized high-resolution MS of POA for the Transporter (a), for the Astra with activated DOC (b, only one experiment), for the Astra with deactivated DOC (c) and for the Astra at $60 \mathrm{~km} / \mathrm{h}$ (d) where the relative contributions of the four organic classes $(\mathrm{CH}, \mathrm{CHO}$, $\mathrm{CHN}, \mathrm{CHON}$ ) to the total organic mass for each mass spectrum are given.

For POA, the organic $\mathrm{CH}$ class is the dominant fraction in the MS for all conditions (75-94\%), followed by the CHO class $(5.5-23 \%)$ and with low contributions from the $\mathrm{CHN}$ and $\mathrm{CHON}$ classes (less than 1.4\%), consistent with the mass spectral characteristics discussed next. POA from the Transporter has a higher contribution from the $\mathrm{CHO}$ class (22.8\%) than the average POA from the other experiments with the Astra (6.7 $\pm 1.0 \%$, average all experiments with Astra).

The primary spectra are dominated by several organic fragment ion groups $\mathrm{C}_{n} \mathrm{H}_{2 n+1}^{+}(\mathrm{m} / z 29,43,57,71, \ldots)$, or alkyl fragments, which are typical of normal and branched alkanes, the series $\mathrm{C}_{n} \mathrm{H}_{2 n-1}^{+}(\mathrm{m} / \mathrm{z}, 27,41,55,69, \ldots)$, typical of cycloalkanes and alkenes, and $\mathrm{C}_{n} \mathrm{H}_{2 n-3}^{+}(\mathrm{m} / z 67,81,95, \ldots)$, typical of cycloalkenes (Canagaratna et al., 2004). The POA mass spectra from all experiments show the largest signal contribution from $m / z, 43$, followed by $m / z, 41$ and slightly lower contributions by $m / z 55$ and $m / z 57$.

Figure 9 indicates that $84 \%$ of POA and more than $93 \%$ of the signal at $\mathrm{m} / 257$ can be assigned to the fragment $\mathrm{C}_{4} \mathrm{H}_{9}^{+}$ for the Transporter (Fig. 9a) and for all types of experiments with the Astra (Fig. 9b, c, d). For $m / z, 43,58 \%$ of the signal at $m / z, 43$ can be assigned to $\mathrm{C}_{3} \mathrm{H}_{7}^{+}$for the Transporter, and more than $87 \%$ for the Astra (the remainder is assigned to the oxygenated fragment $\mathrm{C}_{2} \mathrm{H}_{3} \mathrm{O}^{+}$). $\mathrm{m} / z 44$, typically associated with secondary species in AMS datasets, is also present to a small degree in the POA from the Transporter at about $4.2 \%$ of the total signal $(84.8 \%$ of that signal at $m / z, 44$ is from the CHO family; $75.5 \%$ of the signal at $\mathrm{m} / \mathrm{z}, 44$ is from $\mathrm{CO}_{2}^{+}$, 9.3\% from $\mathrm{C}_{2} \mathrm{H}_{4} \mathrm{O}^{+}$and $3.2 \%$ from $\mathrm{C}_{2} \mathrm{H}_{6} \mathrm{~N}^{+}, 4.1 \%$ from ${ }^{13} \mathrm{CC}_{2} \mathrm{H}_{7}^{+}$, and $7.9 \%$ from $\mathrm{CH}_{2} \mathrm{NO}^{+}$). The contribution of $\mathrm{m} / \mathrm{z} 44$ to the total POA mass for all the experiments with the Astra is around $1 \%(72.5 \%$ of that signal at $\mathrm{m} / \mathrm{z}, 44$ is from the CHO family; $70.3 \%$ of the signal at $m / z, 44$ is from $\mathrm{CO}_{2}^{+}, 2.2 \%$ from $\mathrm{C}_{2} \mathrm{H}_{4} \mathrm{O}^{+}, 7.2 \%$ from $\mathrm{C}_{2} \mathrm{H}_{6} \mathrm{~N}^{+}, 14.7 \%$ from ${ }^{13} \mathrm{CC}_{2} \mathrm{H}_{7}^{+}$, and $5.6 \%$ from $\mathrm{CH}_{2} \mathrm{NO}^{+}$).

A high correlation of the normalized mass spectra of the $\mathrm{CH}$ family was found for the warm idle experiment with activated DOC (Astra) and the warm idle experiments with deactivated DOC (Astra) for the CH family $(R=0.99$, slope $=1.1$, while with activated DOC the MS was more oxidized and lower correlations were found for the $\mathrm{CHO}$ family $(R=0.94$, slope $=0.48)$, CHON family $(R=0.20$, slope $=0.12)$ and the CHN family $(R=0.38$, slope $=0.23)$, with all intercepts forced to zero. This indicates that if there
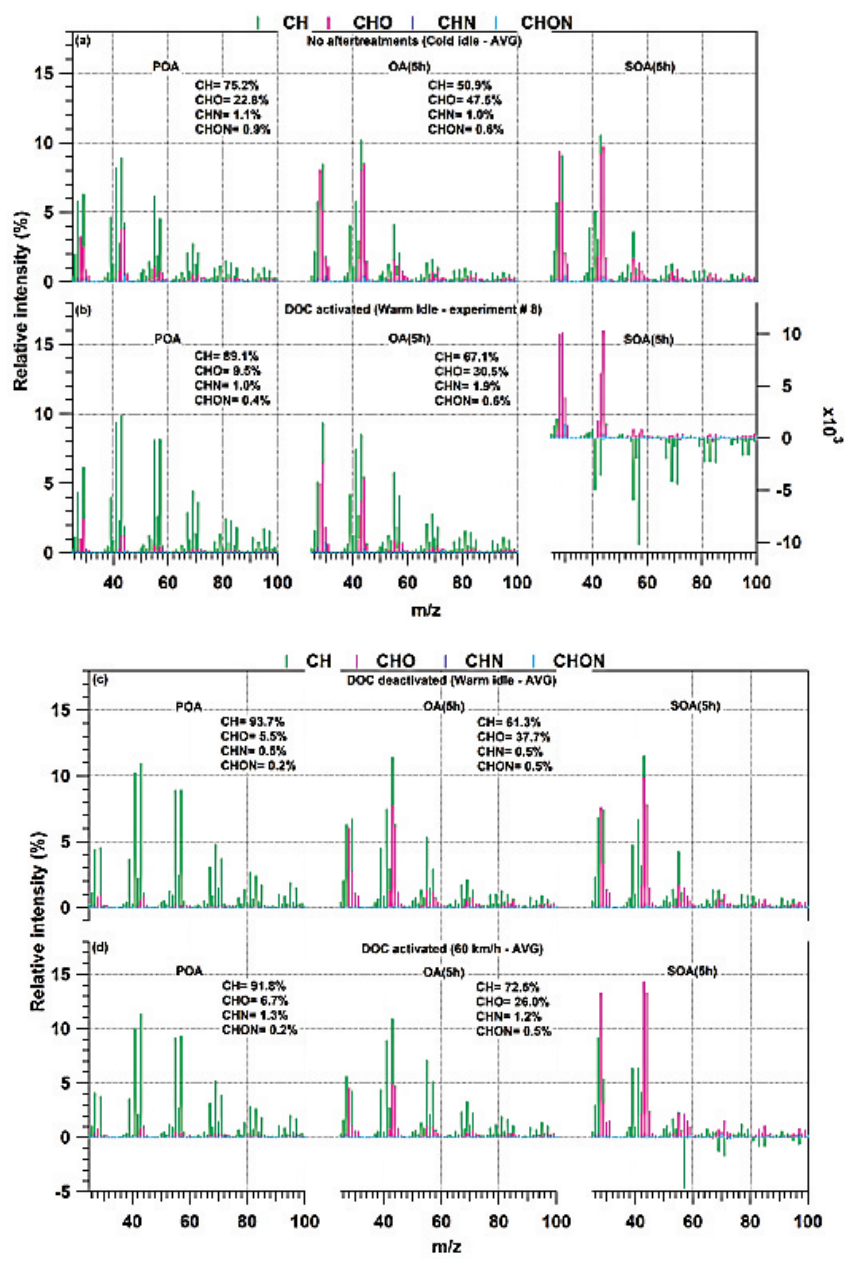

Fig. 9. Average mass spectra in high resolution of POA, OA after $5 \mathrm{~h}$ of aging $(\mathrm{OA}(5 \mathrm{~h}))$ and SOA after 5 hours of aging (SOA $(5 \mathrm{~h})$ ) normalized to the total organic mass from diesel experiments with the Transporter (a), the Astra with activated DOC (b, only one experiment), the Astra with deactivated DOC (c) and the Astra at $60 \mathrm{~km} / \mathrm{h}$ (d).

is an effect of the DOC on the primary MS of diesel exhaust it is not reflected in the $\mathrm{CH}$ family as much as in the other ion families. A high correlation was also found between the HRMS from the Astra at $60 \mathrm{~km} / \mathrm{h}$ and the HR-MS measured during a tunnel study in Switzerland (Chirico et al., 2010b). This MS was measured during rush hours when the average speed of the vehicles was $65 \pm 10 \mathrm{~km} / \mathrm{h}$ yielding correlation coefficients for the different families of: $R_{\mathrm{CH}}=0.99, R_{\mathrm{CHO}}=0.79$, $R_{\mathrm{CHON}}=0.63, R_{\mathrm{CHN}}=0.53$. Note that the OA concentration in the tunnel was a factor of 10 higher than the average POA from the smog chamber experiments at $60 \mathrm{~km} / \mathrm{h}$. The similarity of the MS may indicate that while the higher concentrations of OA influence partitioning, it may not strongly affect the MS of primary OA from diesel vehicles. A comparison between the unit-mass resolution MS (UMR-MS) of POA from the Astra at $60 \mathrm{~km} / \mathrm{h}$ and the UMR-MS from a diesel 
bus chasing experiment (Canagaratna et al., 2004) also shows a strong correlation $(R=0.98$, slope $=0.92)$.

\section{Mass spectral analysis of 5-h aged organic aerosols}

Figure 9 shows how the relative contributions of the different ion classes have evolved in the MS of the total organic aerosol over $5 \mathrm{~h}$ of photooxidation $(\mathrm{OA}(5 \mathrm{~h}))$. The relative contribution of the ion class $\mathrm{CHO}$ to the $\mathrm{OA}((5 \mathrm{~h}))$ grew significantly, in particular for the Transporter to $47.5 \%$ (Fig. 9a). The CHO contribution for the Astra was in the range of 26$37 \%$ (Fig. 9d, b, c). The $\mathrm{CH}$ class remains the dominant part of the MS for the Astra (61-72\%, Fig. 9b, c, d) and also for the Transporter although the CHO family in this case is similar in magnitude (50.9\% CH family Fig. 9a). The CHN and CHON were minor components and combined to $0.2-1.4 \%$ during all experiments.

The condensing oxidized organic molecules did not only contribute to the oxidized families but also to the $\mathrm{CH}$ family, because they are not strongly oxidized and still contain longer non-oxidized chains (see Fig. 6).

The largest single $m / z$ contribution to $\mathrm{OA}(5 \mathrm{~h})$ was due to of $m / z \quad 43(8.5-11.4 \%)$ with the exception of the warm idle experiment (Fig. 9b) when the signal from $\mathrm{m} / \mathrm{z} 29$ was highest (9.3\%). The oxidized ion $\mathrm{C}_{2} \mathrm{H}_{3} \mathrm{O}^{+}$increased significantly and its contribution to the total signal at $m / 2.43$ was: $78.6 \%$ (Fig. 9a); 43.8\% (Fig. 9b); 67.9\% (Fig. 9c); 44.8\% (Fig. 9d).

In the MS of $\mathrm{OA}(5 \mathrm{~h})$ it is also clear that the contribution from mass fragment 44 to total organics increased for all experiments due to photochemistry similar to what is observed in the atmosphere, while the contribution of mass fragment 57 decreased. The relative intensity of $m / z 57$ was below 5\% for all experiments and the contribution of the oxidized fragment $\mathrm{C}_{3} \mathrm{H}_{5} \mathrm{O}^{+}$to $\mathrm{m} / \mathrm{z} 57$ increased in relation to the amount of SOA produced in the chamber. For the experiments with higher SOA production the oxidized fragment $\mathrm{C}_{3} \mathrm{H}_{5} \mathrm{O}^{+}$increased more strongly, as shown previously in Fig. 4. $m / z, 44$ is associated with the carboxylic acid functional group; it dominates the spectra of highly oxygenated organic particles from rural areas and the size distribution of $m / z, 44$ for rural OA is dominated by the accumulation mode and closely resembles that of sulfate, another indicator of secondary particles (Alfarra et al., 2004). The contribution of $\mathrm{m} / \mathrm{z} 44$ to $\mathrm{OA}(5 \mathrm{~h}$ ) was $8.5 \%$ (Fig. 9a); $84.3 \%$ of the signal at $\mathrm{m} / z 44$ is from $\mathrm{CO}_{2}^{+}, 10.7 \%$ from $\mathrm{C}_{2} \mathrm{H}_{4} \mathrm{O}^{+}$ and $1.9 \%$ from $\mathrm{C}_{2} \mathrm{H}_{6} \mathrm{~N}^{+}, 0.8 \%$ from ${ }^{13} \mathrm{CC}_{2} \mathrm{H}_{7}^{+}, 2.3 \%$ from $\mathrm{CH}_{2} \mathrm{NO}^{+}$), $5.5 \%$ (Fig. 9b); $83.6 \%$ from $\mathrm{CO}_{2}^{+}, 4.4 \%$ from $\mathrm{C}_{2} \mathrm{H}_{4} \mathrm{O}^{+}$and $3.8 \%$ from $\mathrm{C}_{2} \mathrm{H}_{6} \mathrm{~N}^{+}, 2.5 \%$ from ${ }^{13} \mathrm{CC}_{2} \mathrm{H}_{7}^{+}$, $5.7 \%$ from $\mathrm{CH}_{2} \mathrm{NO}^{+}$), 6.3\% (Fig. 9c); $85.7 \%$ from $\mathrm{CO}_{2}^{+}$, $9.0 \%$ from $\mathrm{C}_{2} \mathrm{H}_{4} \mathrm{O}^{+}$and $0.4 \%$ from $\mathrm{C}_{2} \mathrm{H}_{6} \mathrm{~N}^{+}, 1.0 \%$ from ${ }^{13} \mathrm{CC}_{2} \mathrm{H}_{7}^{+}, 2.1 \%$ from $\mathrm{CH}_{2} \mathrm{NO}^{+}$) and $4.7 \%$ (Fig. $9 \mathrm{~d}$ ); $84.3 \%$ from $\mathrm{CO}_{2}^{+}, 10.7 \%$ from $\mathrm{C}_{2} \mathrm{H}_{4} \mathrm{O}^{+}$and $1.9 \%$ from $\mathrm{C}_{2} \mathrm{H}_{6} \mathrm{~N}^{+}$, $0.8 \%$ from ${ }^{13} \mathrm{CC}_{2} \mathrm{H}_{7}^{+}, 2.3 \%$ from $\mathrm{CH}_{2} \mathrm{NO}^{+}$).
Other ions in the OA $(5 \mathrm{~h})$ that also showed a significantly enhanced contribution to the $\mathrm{CHO}$ class were $\mathrm{CHO}^{+}(\mathrm{m} / \mathrm{z}$ 29) and $\mathrm{CH}_{3} \mathrm{O}^{+}(\mathrm{m} / \mathrm{z}, 31)$. In all experiments the contributions of these ions to the normalized organic signal increased by at least a factor of 2 . While assignment of these ions to particular functionalities is not possible, they likely arise in part from aldehydes, hydroxyl groups, and esters or ethers.

\section{Mass spectral analysis and estimation of SOA MS}

Although we have shown previously that POA is not likely to be inert during the photooxidation experiments, it is useful to determine an approximate mass spectrum of the SOA formed during the POA + SOA experiments. This high resolution mass spectrum was estimated after $5 \mathrm{~h}$ of aging $(\mathrm{SOA}(5 \mathrm{~h}))$ by calculating each ion contribution to the SOA mass spectrum using the following equation:

$I_{\mathrm{SOA}(5 \mathrm{~h})}=\left[I_{\mathrm{OA}(5 \mathrm{~h})} \times\left(\mathrm{BC}\left(t_{0}\right) / \mathrm{BC}(5 \mathrm{~h})\right]-I_{\mathrm{POA}}\right.$,

where $I_{\mathrm{OA}(5 \mathrm{~h})}$ and $I_{\mathrm{POA}}$ are the signal intensities of each ion after $5 \mathrm{~h}$ of aging and before lights on, respectively. Figure 9 shows the normalized SOA mass spectra calculated from Eq. (7). The $I_{\mathrm{SOA}(5 \mathrm{~h})}$ signals for some non-oxidized ions that contribute to the $\mathrm{CH}$ family were negative after $5 \mathrm{~h}$ of aging indicating that the loss processes for these ions, i.e., volatilization and/or heterogeneous chemistry, were higher than the gain through condensation (see Fig. S6). The loss processes of organic molecules, with a corresponding reduction of some non-oxidized ions, were most evident for the experiments at $60 \mathrm{~km} / \mathrm{h}$ and for the warm idle experiment with activated DOC because there was less SOA production. The ions with negative values belong to the $\mathrm{CH}$ family and contribute to $\mathrm{m} / \mathrm{z} 29,41,43,55,56,57,67,69,71,83,85,97$ and 99. The other MS in Fig. S6 obtained with Eq. (7) are from experiments where the SOA production was higher than the SOA production for the $60 \mathrm{~km} / \mathrm{h}$ experiments, thus the loss processes for these ions were either slower and/or balanced by the addition of secondary organics.

For the experiments with higher SOA production the relative contribution of the $\mathrm{CHO}$ family to $\mathrm{SOA}(5 \mathrm{~h})$ was $54 \%$ and 47\% for the Transporter (Fig. 9a) and the Astra (Fig. 9c), respectively, while the contribution of the $\mathrm{CH}$ family was $44 \%$ and $52 \%$. The highest ion intensities in the $\operatorname{SOA}(5 \mathrm{~h})$ MS were at $m / z, 33$ and 44 where the oxidized ions were responsible for most of the signal. The experiment \#8 (Astra, warm idle, activated DOC) was the experiment with the lowest relative contribution of SOA (only $\sim 10 \%$ of the total organic mass was SOA after $5 \mathrm{~h}$ of aging), and the MS of $\mathrm{SOA}(5 \mathrm{~h})$ in Fig. 9b clearly shows that for the $\mathrm{CH}$ ions the loss processes, volatilization and/or heterogeneous chemistry, dominated over the gain through condensation. The total $\mathrm{CH}$ signal from OA $(5 \mathrm{~h})$ decreased by $25 \%$ compared to the signal from POA. The loss of the POA signature in ambient air after 1-2 days of transport was recently reported for measurements in Crete by Hildebrandt et al. (2010). 


\subsubsection{Gas-phase only photooxidation experiments}

Aging experiments of diesel exhaust without the particulate phase were performed with 3 different vehicles: the Citroen (DOC and diesel particle filter, DPF), the Transporter (no DOC) and the Astra (only DOC). For the vehicles not equipped with a filter, the sample was injected into the chamber with the filtering system shown in Fig. 1 heated to $150^{\circ} \mathrm{C}$.

After introduction of the exhaust into the chamber with the heated filter system the particle number concentration measured with a condensation particle counter (CPC, Model $3025 \mathrm{~A}$, TSI) was low $\left(2.5 \pm 0.5 \mathrm{~cm}^{-3}\right)$ indicating the high removal efficiency of the filter (exp. \# 12, 18 and 19). For the experiment with the Citroen the sample bypassed the heated filter and was directly injected. For these experiments the particle number concentration measured in the chamber was $300 \pm 19 \mathrm{~cm}^{-3}$.

The particle number concentration started to increase after $\sim 12 \mathrm{~min}$, and about $50 \mathrm{~min}$ after lights on the particle number concentration from all gas-phase only experiments increased to a maximum of $70950 \pm 5900 \mathrm{~cm}^{-3}$. The AMS started to detect particulate mass after $28 \pm 4 \mathrm{~min}$ after lights on and the average first-order wall-loss corrected SOA produced after $5 \mathrm{~h}$ of aging $\left(\mathrm{SOA}_{\mathrm{WLC}}^{\mathrm{FO}}(5 \mathrm{~h})\right)$ was $6.1 \pm 4.4 \mu \mathrm{g} / \mathrm{m}^{3}$. The average relative contribution of the signal at $m / z \quad 44$ to the total organic signal $\left(f_{44}\right)$ from all experiments was $8.6 \pm 1.7 \%$ after $1.4 \mathrm{~h}$ of lights on. After $5 \mathrm{~h}$ of aging $f_{44}$ was $9.7 \pm 2.2 \%$. Experiment \#18 in Table 1 was a longer experiment where the initial $f_{44}$ value for the SOA produced in the chamber, after $\sim 1 \mathrm{~h}$ of aging, was $7.6 \pm 0.5 \%$ and increased to $9.8 \pm 0.6 \%$ after $20 \mathrm{~h}$.

For the four gas-phase only experiments $\mathrm{C}_{4} \mathrm{H}_{9}^{+}$contributed around $40 \%$ to the signal at $m / z, 57$ after $5 \mathrm{~h}$ (Fig. 10). This value is similar to the values obtained with the experiments with high SOA production (Transporter, Astra with deactivated DOC, Fig. 4). This corroborates the fact that alkyl fragments also comprise a non-negligible part of the SOA mass spectrum. For the longer experiment \#18 the percentage of $\mathrm{C}_{4} \mathrm{H}_{9}$ at $\mathrm{m} / z .57$ decreased to $26 \%$ after $20 \mathrm{~h}$ of photooxidation.

Figure $\mathrm{S} 7$ reports the ratios $\mathrm{H} / \mathrm{C}, \mathrm{O} / \mathrm{C}$, and $\mathrm{OM} / \mathrm{OC}$ for the gas-phase only experiments. During the first $5 \mathrm{~h}$ the average $\mathrm{H} / \mathrm{C}$ ratio from all experiments was $1.56 \pm 0.05$, the average $\mathrm{O} / \mathrm{C}$ ratio was $0.37 \pm 0.07$, and the average $\mathrm{OM} / \mathrm{OC}$ ratio was $1.64 \pm 0.10$. For the 20 -h experiment the $\mathrm{H} / \mathrm{C}$ ratio was $1.56 \pm 0.02$ during the first $5 \mathrm{~h}$ and $1.54 \pm 0.02$ after $20 \mathrm{~h}$ of aging, while during the same time the $\mathrm{O} / \mathrm{C}$ ratio increased from $0.40 \pm 0.02$ to $0.49 \pm 0.02$ and the $\mathrm{OM} / \mathrm{OC}$ ratio from $1.68 \pm 0.03$ to $1.80 \pm 0.02$. These values are consistent with the ones of Fig. 8, where the mass spectrum is dominated by SOA.

Figure 11a shows the average high-resolution mass spectra of $\operatorname{SOA}(5 \mathrm{~h})$ from the experiments with the Transporter (\#18 and 19 in Table 1), when a DPF was simulated with the filtering system mounted in the sampling line. The aver-

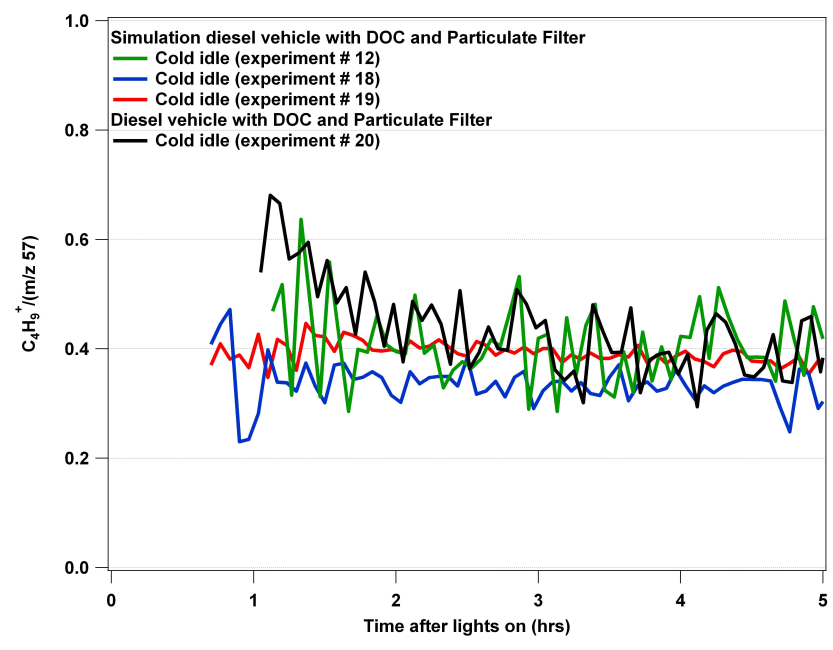

Fig. 10. Time series of the fraction of $\mathrm{C}_{4} \mathrm{H}_{9}^{+}$to total $\mathrm{m} / \mathrm{z}, 57$ signal from the diesel gas-phase only experiments.

age $\mathrm{SOA}_{\mathrm{WLC}}^{\mathrm{FO}}(5 \mathrm{~h}) \mathrm{MS}$ shows that the $\mathrm{CH}$ family contributed $51.9 \%$, to the organic mass, the CHO family $46.8 \%$, the CHN family $0.50 \%$, and the CHON family $0.80 \%$. The largest signal contribution was at $\mathrm{m} / z, 43$ followed by 29 and 44 . The signal at $\mathrm{m} / \mathrm{z} 44$ was almost completely due to the $\mathrm{CHO}$ family (82\% of the signal at $\mathrm{m} / z$, 44 is from $\mathrm{CO}_{2}^{+}, 8.7 \%$ from $\mathrm{C}_{2} \mathrm{H}_{4} \mathrm{O}^{+}$and $1.7 \%$ from $\mathrm{C}_{2} \mathrm{H}_{6} \mathrm{~N}^{+}$), while the contribution of the CHO family was $77.9 \%$ to $\mathrm{m} / \mathrm{z}, 43,57.2 \%$ to $\mathrm{m} / \mathrm{z} 29$ and $64.1 \%$ to $\mathrm{m} / z$ 57. The scatter plot between the gas phase only $\mathrm{SOA}_{\mathrm{WLC}}^{\mathrm{FO}}(5 \mathrm{~h})$ and the average calculated $\mathrm{SOA}(5 \mathrm{~h})$ from the same vehicle (Transporter) during POA + SOA experiments using Eq. (7) (experiments \#13 to 17 in Table 1) is shown in Fig. 11b. It shows that the method used to obtain the SOA MS (Eq. 7) yields a similar spectrum as the SOA MS directly measured from the gas-phase only photooxidation experiments. The slopes of the orthogonal distance regressions with the intercept forced to zero were 0.87 for $\mathrm{CH}, 1.2$ for CHO, and 1.1 for CHON and CHN. The Pearson's correlation coefficients were: 0.982 for $\mathrm{CH}, 0.991$ for $\mathrm{CHO}, 0.984$ for $\mathrm{CHON}$, and 0.998 for $\mathrm{CHN}$.

The contributions to SOA from the long experiment (\#18) were as follows: after $5 \mathrm{~h}: 45.3 \%$ from the $\mathrm{CH}$ family, $53.1 \%$ from the CHO family, $1.06 \%$ from the CHN family, and $0.54 \%$ from the CHON family; after $20 \mathrm{~h}$, while the $\mathrm{CH}$ contribution to the SOA was $39.7 \%$, the one of $\mathrm{CHO}$ was $57.2 \%$ and the contribution of $\mathrm{CHN}$ and $\mathrm{CHON}$ were $2.54 \%$ and $0.56 \%$, respectively.

\subsubsection{Emission factors for POA, SOA and BC}

The emissions factors for POA, SOA and BC, calculated with Eq. (1), for all experiments are shown in Fig. 12.

POA emissions showed less dependence on the presence of a DOC than the SOA formation. In fact, the average $\mathrm{EF}(\mathrm{POA})$ was $0.081(\mathrm{~g} / \mathrm{kg}$ fuel) and $0.147(\mathrm{~g} / \mathrm{kg}$ fuel) for the 


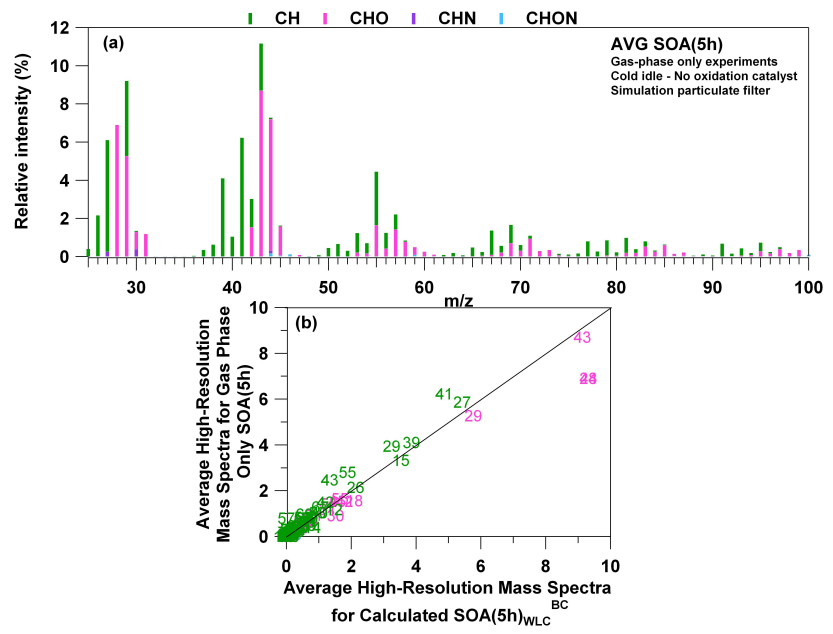

Fig. 11. (a) Average high-resolution mass spectrum of SOA after $5 \mathrm{~h}$ of aging from the diesel gas-phase only experiments ( $\mathrm{SOA}(5 \mathrm{~h})$, experiments \#18 and 19 in Table 1) with the Transporter. (b) Scatter plot between the mass spectrum of $\operatorname{SOA}(5 \mathrm{~h})$ versus the average SOA mass spectrum for the Transporter estimated with Eq. (7) for experiments \#13 and 17 in Table 1.

experiments with the Transporter and the Astra with deactivated DOC, respectively, while for the experiments with an activated DOC the EF(POA) was $0.143(\mathrm{~g} / \mathrm{kg}$ fuel) (warm idle) and 0.137 (g/kg fuel) (cold idle). Also the EF(POA) for the experiments at $60 \mathrm{~km} / \mathrm{h}$ was similar to the values from the idle experiments. The $\mathrm{EF}(\mathrm{SOA})$ values were $0.254(\mathrm{~g} / \mathrm{kg}$ fuel) (Transporter, no DOC) and 0.461 (g/kg fuel) (Astra, deactivated DOC), while values below 0.047 ( $\mathrm{g} / \mathrm{kg}$ fuel) were obtained in presence of a DOC (idle and $60 \mathrm{~km} / \mathrm{h}$ experiments). For the experiments at $60 \mathrm{~km} / \mathrm{h}$ the emission factors of POA and SOA were comparable to those from the same vehicle with activated DOC at idle mode. Figure 12 shows that in the presence of both a DOC and a DPF the total particulate mass, the emitted primary mass plus the produced secondary mass after $5 \mathrm{~h}$ was drastically reduced.

In the absence of a DOC, $47-59 \%$ of the primary mass $(\mathrm{POA}+\mathrm{BC})$ plus the produced secondary mass $(5 \mathrm{~h})$ was made of BC, $31-40 \%$ of SOA and $10-13 \%$ of POA. With a DOC, BC still dominated the overall mass $(\sim 74-83 \%)$ while SOA was drastically reduced $(\sim 2-7 \%)$.

\section{Conclusions}

In this paper we present the first characterization of POA and estimates of the SOA formation from one vehicle without aftertreatment and from two vehicles with aftertreatment devices (one with only a DOC and another one with DOC and particulate filter). In addition, we show the high mass resolution MS of POA, aged OA and SOA from diesel exhaust measured by an Aerodyne aerosol mass spectrometer. POA

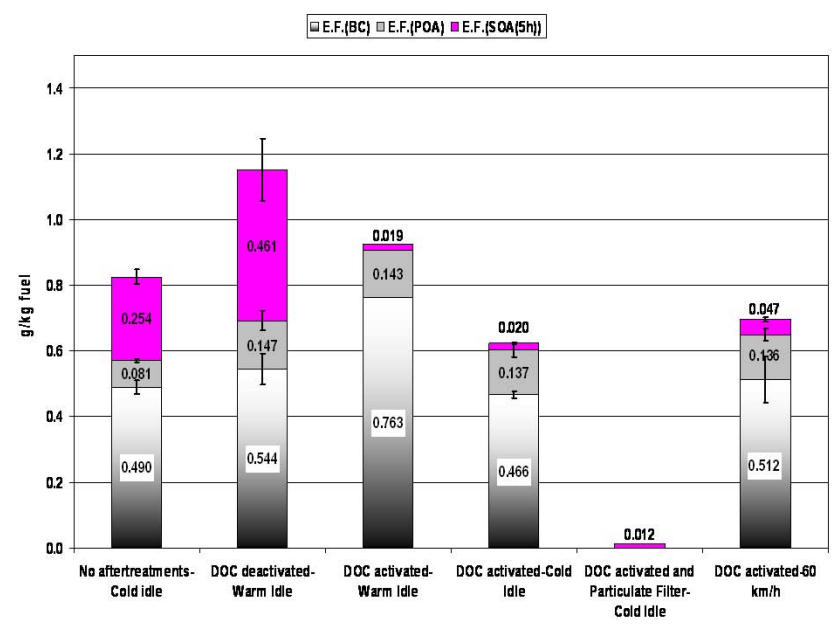

Fig. 12. Emission factors from in-use vehicles of POA, SOA and BC calculated with Eq. (1).

emission and SOA formation depend on various factors such as engine temperature and load, aftertreatment devices, dilution of exhaust and organic aerosol loading.

Two methods were tested to quantify the SOA production; first, $\mathrm{BC}$ measurements were used to account for wall losses in the chamber and to estimate the SOA production, and second, the ion $\mathrm{C}_{4} \mathrm{H}_{9}^{+}$, a marker of primary diesel $\mathrm{OA}$, was used. The two methods agreed well in cases with high SOA production, but diverged for conditions with low SOA production. For the $\mathrm{C}_{4} \mathrm{H}_{9}^{+}$and other alkyl ions the IER showed a varying behavior and a strong dependence on the amount of SOA formed during an experiment. This implies that the POA mass spectrum is not stable over the course of an experiment, and using individual ions to calculate SOA fractions can result in an over or underestimation of SOA depending on the behavior (increasing or decreasing) of the ion used. The reason for a good agreement between the $\mathrm{C}_{4} \mathrm{H}_{9}^{+}$method with the $\mathrm{BC}$ estimate is that the formation of $\mathrm{C}_{4} \mathrm{H}_{9}^{+}$ions during SOA formation compensates for the losses due to volatilization and reaction. The use of BC as a wall loss tracer was more reliable and less affected by artifacts. A comparison between BC measurements with a MAAP, Aethalometer and SP2 showed that the enhancement of the MAE caused by the organic coating seems to be below $10 \%$ in our experiments. Therefore we used the BC wall loss correction as the primary method. It is concluded from our analysis that it is important to evaluate the method applied for the SOA quantification and the artifacts associated to it.

For the conditions explored in this paper, it could be shown that the directly emitted aerosol consists mainly of $\mathrm{BC}$ with a low fraction of organic matter $(\mathrm{OM} / \mathrm{BC}<0.5)$. When the exhaust was subjected to photochemical oxidation in a smog chamber SOA production occurred for all vehicles. The presence of a DOC interestingly had no measurable effect on the emission factor of POA, while it substantially reduced SOA 
formation. POA emission factors were between 0.08 to 0.15 (g/kg fuel) for all vehicles and conditions (idle, $60 \mathrm{~km} / \mathrm{h}$ ). The lack of influence of the DOC on primary organic aerosol formation deserves further investigation. The $\mathrm{EF}(\mathrm{SOA})$ values were $0.254(\mathrm{~g} / \mathrm{kg}$ fuel) (Transporter, no DOC) and 0.461 ( $\mathrm{g} / \mathrm{kg}$ fuel) (Astra, deactivated DOC), while values below $0.047(\mathrm{~g} / \mathrm{kg}$ fuel $)$ were obtained in the presence of a DOC (idle and $60 \mathrm{~km} / \mathrm{h}$ experiments). The vehicle with a DOC and a particulate filter yielded only a $\mathrm{EF}(\mathrm{SOA})$ of $0.012(\mathrm{~g} / \mathrm{kg}$ fuel). While a DOC does not reduce primary particle emissions $(\mathrm{BC}+\mathrm{POA})$ it reduces the SOA formation by more than a factor of 23 for the same car at the same driving conditions (Astra, idle). Most efficient is a particle filter in combination with a DOC which reduces total particle formation around 50 times.

The POA MS had a similar fragmentation pattern for the different conditions and the $\mathrm{CH}$ family was the dominant class of ions $(92 \pm 2 \%$ of the total organic mass, average from all experiments with the car equipped with DOC; $75 \%$ for the experiments with the car without DOC). The MS analysis of the SOA after $5 \mathrm{~h}$ of aging, from gas-phase only experiments, showed a fraction of signal due to the $\mathrm{CHO}$ family equal to $47 \%$, which is consistent with the more oxidized nature of the SOA compared to POA.

We also determined the $\mathrm{O} / \mathrm{C}$ and $\mathrm{H} / \mathrm{C}$ atomic ratios and the OM/OC ratio of the OA. The primary OA had a low $\mathrm{O} / \mathrm{C}$ ratio $(\sim 0.07-0.18$, all experiments). Photochemistry in the smog chamber then increased the $\mathrm{O} / \mathrm{C}$ for the OA after $5 \mathrm{~h}$ of aging $(\sim 0.20-0.37)$ and at the same time the $\mathrm{H} / \mathrm{C}$ ratio decreased as expected. The OM/OC ratio for the primary emissions was $\sim 1.28-1.40$ (all experiments) and for the $\mathrm{OA}(5 \mathrm{~h})$ it increased to $\sim 1.45-1.63$. The low $\mathrm{O} / \mathrm{C}$ ratio measured after aging is lower than ambient values $(\sim 0.25-1)$, which is plausible considering the facts that the ambient aerosol includes other components with a higher $\mathrm{O} / \mathrm{C}$ ratio and that the aging time was only $5 \mathrm{~h}$.

\section{Supplementary material related to this article is available online at: http://www.atmos-chem-phys.net/10/11545/2010/ acp-10-11545-2010-supplement.zip.}

Acknowledgements. The authors thank Panayotis Dimopoulos, Daniel Schreiber and Silke Weimer for the information that they provided. PFD is grateful for postdoctoral research support from the US-NSF (IRFP \#0701013). This work was supported by the Competence Center Energy and Mobility (CCEM) in the context of the project NEADS as well as the Swiss National Science Foundation.

Edited by: H. Saathoff

\section{References}

ACEA: EU Economic Report February 2008, available at: http://www.acea.be/index.php/collection/publications (last access: March 2009), 2008.

Aiken, A. C., DeCarlo, P. F., and Jimenez, J. L.: Elemental analysis of organic species with electron ionization high-resolution mass spectrometry, Anal. Chem., 79, 8350-8358, 2007.

Aiken, A. C., DeCarlo, P. F., Kroll, J. H., Worsnop, D. R., Huffman, J. A., Docherty, K. S., Ulbrich, I. M., Mohr, C., Kimmel, J. R., Sueper, D., Sun, Y., Zhang, Q., Trimborn, A., Northway, M., Ziemann, P. J., Canagaratna, M. R., Onasch, T. B., Alfarra, M. R., Prevot, A. S. H., Dommen, J., Duplissy, J., Metzger, A., Baltensperger, U., and Jimenez, J. L.: O/C and OM/OC ratios of primary, secondary, and ambient organic aerosols with high-resolution time-of-flight aerosol mass spectrometry, Environ. Sci. Technol., 42, 4478-4485, 2008.

Alfarra, M. R., Coe, H., Allan, J. D., Bower, K. N., Boudries, H., Canagaratna, M. R., Jimenez, J. L., Jayne, J. T., Garforth, A. A., Li, S.-M., and Worsnop, D. R.: Characterization of urban and rural organic particulate in the Lower Fraser Valley using two Aerodyne Aerosol Mass Spectrometers, Atmos. Environ., 38, 5745-5758, 2004.

Allan, J. D., Delia, A. E., Coe, H., Bower, K. N., Alfarra, M. R., Jimenez, J. L., Middlebrook, A. M., Drewnick, F., Onasch, T. B., Canagaratna, M. R., Jayne, J. T., and Worsnop, D. R.: A generalised method for the extraction of chemically resolved mass spectra from Aerodyne aerosol mass spectrometer data, J. Aerosol Sci., 35, 909-922, 2004.

Andersson, J., Antonsson, M., Eurenius, L., Olsson, E., and Skoglundh, M.: Deactivation of diesel oxidation catalysts: Vehicle- and synthetic aging correlations, Appl. Catal. BEnviron., 72, 71-81, 2007.

Atkinson, R. and Arey, J.: Atmospheric degradation of volatile organic compounds, Chem. Rev., 103, 4605-4638, 2003.

Baltensperger, U. and Prevot, A. S. H.: Chemical analysis of atmospheric aerosols, Anal. Bioanal. Chem., 390, 277-280, 2008.

Bosteels, D., May, J., Karlsson, H., and de Serves, C.: 'Regulated' and 'non-regulated' emissions from modern European passenger cars, SAE Technical Paper Series, 2006-01-1516, 1-9, 2006.

Canagaratna, M. R., Jayne, J. T., Ghertner, D. A., Herndon, S., Shi, Q., Jimenez, J. L., Silva, P. J., Williams, P., Lanni, T., Drewnick, F., Demerjian, K. L., Kolb, C. E., and Worsnop, D. R.: Chase studies of particulate emissions from in-use New York City vehicles, Aerosol Sci. Tech., 38, 555-573, 2004.

Chirico, R., Clairotte, M., Adam, T., Heringa, M. F., DeCarlo, P. F., Giechaskiel, B., Elsasser, M., Astorga, C., Streibel, T., Sklorz, M., Zimmermann, R., Martini, G., Baltensperger, U., and Prevot, A. S. H.: Chassis dynamometer measurements of organic mass, black carbon, particle number, and regulated and unregulated gas emissions from mopeds and light and heavy duty vehicles, in preparation, 2010a.

Chirico, R., DeCarlo, P. F., Heringa, M. F., Prevot, A. S. H., Richter, R., and Baltensperger, U.: Aerosol and trace gas emissions in a road tunnel measured by Aerosol Mass Spectrometry and other on-line instrumentation, Atmos. Environ., submitted, $2010 \mathrm{~b}$.

Cocker, D. R. I., Mader, B. T., Kalberer, M., Flagan, R. C., and Seinfeld, J. H.: The effect of water on gas-particle partitioning of secondary organic aerosol: II. m-xylene and 1,3,5-trimethylbenzene photooxidation systems, Atmos. Environ., 35, 6073-6085, 2001. 
DeCarlo, P. F., Slowik, J. G., Worsnop, D. R., Davidovits, P., and Jimenez, J. L.: Particle morphology and density characterization by combined mobility and aerodynamic diameter measurements. Part 1: Theory, Aerosol Sci. Technol., 38, 1185-1205, 2004.

DeCarlo, P. F., Kimmel, J. R., Trimborn, A., Northway, M. J., Jayne, J. T., Aiken, A. C., Gonin, M., Fuhrer, K., Horvath, T., Docherty, K. S., Worsnop, D. R., and Jimenez, J. L.: Field-deployable, high-resolution, time-of-flight aerosol mass spectrometer, Anal. Chem., 78, 8281-8289, 2006.

DeCarlo, P. F., Ulbrich, I. M., Crounse, J., de Foy, B., Dunlea, E. J., Aiken, A. C., Knapp, D., Weinheimer, A. J., Campos, T., Wennberg, P. O., and Jimenez, J. L.: Investigation of the sources and processing of organic aerosol over the Central Mexican Plateau from aircraft measurements during MILAGRO, Atmos. Chem. Phys., 10, 5257-5280, doi:10.5194/acp-10-52572010, 2010.

Fino, D.: Diesel emission control: Catalytic filters for particulate removal, Sci. Technol. Adv. Mat., 8, 93-100, 2007.

Giechaskiel, B., Chirico, R., DeCarlo, P. F., Clairotte, M., Adam, T., Martini, G., Heringa, M. F., Richter, R., Prevot, A. S. H., Baltensperger, U., and Astorga, C.: Evaluation of the particle measurement programme (PMP) protocol to remove the vehicles' exhaust aerosol volatile phase, Sci. Total Environ., 408, 51065116, 2010.

Grieshop, A. P., Logue, J. M., Donahue, N. M., and Robinson, A. L.: Laboratory investigation of photochemical oxidation of organic aerosol from wood fires 1: measurement and simulation of organic aerosol evolution, Atmos. Chem. Phys., 9, 1263-1277, doi:10.5194/acp-9-1263-2009, 2009.

Hildebrandt, L., Engelhart, G. J., Mohr, C., Kostenidou, E., Lanz, V. A., Bougiatioti, A., DeCarlo, P. F., Prevot, A. S. H., Baltensperger, U., Mihalopoulos, N., Donahue, N. M., and Pandis, S. N.: Aged organic aerosol in the Eastern Mediterranean: the Finokalia Aerosol Measurement Experiment 2008, Atmos. Chem. Phys., 10, 4167-4186, doi:10.5194/acp-10-4167-2010, 2010.

Jimenez, J. L., Canagaratna, M. R., Donahue, N. M., Prevot, A. S. H., Zhang, Q., Kroll, J. H., DeCarlo, P. F., Allan, J. D., Coe, H., Ng, N. L., Aiken, A. C., Docherty, K. S., Ulbrich, I. M., Grieshop, A. P., Robinson, A. L., Duplissy, J., Smith, J. D., Wilson, K. R., Lanz, V. A., Hueglin, C., Sun, Y. L., Tian, J., Laaksonen, A., Raatikainen, T., Rautiainen, J., Vaattovaara, P., Ehn, M., Kulmala, M., Tomlinson, J. M., Collins, D. R., Cubison, M. J., Dunlea, J., Huffman, J. A., Onasch, T. B., Alfarra, M. R., Williams, P. I., Bower, K., Kondo, Y., Schneider, J., Drewnick, F., Borrmann, S., Weimer, S., Demerjian, K., Salcedo, D., Cottrell, L., Griffin, R., Takami, A., Miyoshi, T., Hatakeyama, S., Shimono, A., Sun, J. Y., Zhang, Y. M., Dzepina, K., Kimmel, J. R., Sueper, D., Jayne, J. T., Herndon, S. C., Trimborn, A. M., Williams, L. R., Wood, E. C., Middlebrook, A. M., Kolb, C. E., Baltensperger, U., and Worsnop, D. R.: Evolution of organic aerosols in the atmosphere, Science, 326, 1525-1529, doi:10.1126/science.1180353, 2009.

Katare, S. R., Patterson, J. E., and Laing, P. M.: Diesel aftertreatment modeling: A systems approach to NOx control, Ind. Eng Chem. Res., 46, 2445-2454, doi:10.1021/ie0612515, 2007.

Kittelson, D. B.: Engines and nanoparticles: a review, J. Aerosol Sci., 29, 575-588, 1998.

Kozak, M. and Jerzy, M.: The mechanics of fuel sulphur influence on exhaust emissions from diesel engines, TEKA Kom. Energ.
Roln., 5, 96-106, 2005.

Kweon, C. B., Okada, S., Foster, D. E., Bae, M. S., and Schauer, J. J.: Effect of engine operating conditions on particle-phase organic compounds in engine exhaust of a heavy-duty, direct- injection (D.I.) diesel engine, SAE Technical Paper Series, 200301-0342, 73-89, 2003.

Lanz, V. A., Alfarra, M. R., Baltensperger, U., Buchmann, B., Hueglin, C., and Prévôt, A. S. H.: Source apportionment of submicron organic aerosols at an urban site by factor analytical modelling of aerosol mass spectra, Atmos. Chem. Phys., 7, 1503-1522, doi:10.5194/acp-7-1503-2007, 2007.

Lanz, V. A., Prévôt, A. S. H., Alfarra, M. R., Weimer, S., Mohr, C., DeCarlo, P. F., Gianini, M. F. D., Hueglin, C., Schneider, J., Favez, O., D’ Anna, B., George, C., and Baltensperger, U.: Characterization of aerosol chemical composition with aerosol mass spectrometry in Central Europe: an overview, Atmos. Chem. Phys., 10, 10453-10471, doi:10.5194/acp-10-10453-2010, 2010.

Leskinen, A. P., Jokiniemi, J. K., and Lehtinen, K. E. J.: Transformation of diesel engine exhaust in an environmental chamber, Atmos. Environ., 41, 8865-8873, 2007.

Lipsky, E. M. and Robinson, A. L.: Effects of dilution on fine particle mass and partitioning of semivolatile organics in diesel exhaust and wood smoke, Environ. Sci. Technol., 40, 155-162, 2006.

Liu, P. S. K., Deng, R., Smith, K. A., Williams, L. R., Jayne, J. T., Canagaratna, M. R., Moore, K., Onasch, T. B., Worsnop, D. R., and Deshler, T.: Transmission efficiency of an aerodynamic focusing lens system: Comparison of model calculations and laboratory measurements for the Aerodyne aerosol mass spectrometer, Aerosol Sci. Tech., 41, 721-733, 2007.

Matthew, B. M., Middlebrook, A. M., and Onasch, T. B.: Collection efficiencies in an Aerodyne aerosol mass spectrometer as a function of particle phase for laboratory generated aerosols, Aerosol Sci. Tech., 42, 884-898, 2008.

Moteki, N. and Kondo, Y.: Effects of mixing state on black carbon measurements by laser-induced incandescence, Aerosol Sci. Technol., 41, 398-417, 2007.

Odum, J. R., Hoffmann, T., Bowman, F., Collins, D., Flagan, R. C., and Seinfeld, J. H.: Gas/particle partitioning and secondary organic aerosol yields, Environ. Sci. Technol., 30, 2580-2585, doi:10.1021/es950943+, 1996.

Pankow, J. F.: An absorption model of the gas/aerosol partitioning involved in the formation of secondary organic aerosol, Atmos. Environ., 28, 189-193, 1994a.

Pankow, J. F.: An absorption model of gas/particle partitioning of organic compounds in the atmosphere, Atmos. Environ., 28, 185-188, 1994b.

Paulsen, D., Dommen, J., Kalberer, M., Prevot, A. S. H., Richter, R., Sax, M., Steinbacher, M., Weingartner, E., and Baltensperger, U.: Secondary organic aerosol formation by irradiation of 1,3,5trimethylbenzene- $\mathrm{NO}_{\mathrm{x}}-\mathrm{H}_{2} \mathrm{O}$ in a new reaction chamber for atmospheric chemistry and physics, Environ. Sci. Technol., 39, 2668-2678, 2005.

Phuleria, H. C., Geller, M. D., Fine, P. M., and Sioutas, C.: Sizeresolved emissions of organic tracers from light- and heavy-duty vehicles measured in a California roadway tunnel, Environ. Sci. Technol., 40, 4109-4118, 2006.

Pope, C. A. and Dockery, D. W.: Health effects of fine particulate air pollution: Lines that connect, 99th Annual Meeting of the Air- 
and-Waste-Management-Association, New Orleans, LA, 2006, ISI:000238176000002, 709-742, 2006.

Robinson, A. L., Donahue, N. M., Shrivastava, M. K., Weitkamp, E. A., Sage, A. M., Grieshop, A. P., Lane, T. E., Pierce, J. R., and Pandis, S. N.: Rethinking organic aerosols: Semivolatile emissions and photochemical aging, Science, 315, 1259-1262, doi:10.1126/science.1133061, 2007.

Sage, A. M., Weitkamp, E. A., Robinson, A. L., and Donahue, N. M.: Evolving mass spectra of the oxidized component of organic aerosol: results from aerosol mass spectrometer analyses of aged diesel emissions, Atmos. Chem. Phys., 8, 1139-1152, doi:10.5194/acp-8-1139-2008, 2008.

Schauer, J. J., Kleeman, M. J., Cass, G. R., and Simoneit, B. R. T.: Measurement of emissions from air pollution sources. 2. C1 through C30 organic compounds from medium duty diesel trucks, Environ. Sci. Technol., 33, 1578-1587, 1999.

Schnaiter, M., Linke, C., Möhler, O., Naumann, K. H., Saathoff, H., Wagner, R., Schurath, U., and Wehner, B.: Absorption amplification of black carbon internally mixed with secondary organic aerosol, J. Geophys. Res., 110, D19204, doi:10.1029/2005JD006046, 2005.

Schneider, J., Weimer, S., Drewnick, F., Borrmann, S., Helas, G., Gwaze, P., Schmid, O., Andreae, M. O., and Kirchner, U.: Mass spectrometric analysis and aerodynamic properties of various types of combustion-related aerosol particles, Int. J. Mass Spectrom., 258, 37-49, 2006.

Shah, S. P., Cocker III, D. R., Miller, J. W., and Norbeck, J. M.: Emission rates of particulate matter and elemental and organic carbon from in-use diesel engines, Environ. Sci. Technol., 38, 2544-2550, 2004.

Sharma, M., Agarwal, A. K., and Bharathi, K. V. L.: Characterization of exhaust particulates from diesel engine, Atmos. Environ., 39, 3023-3028, 2005.

Shiraiwa, M., Kondo, Y., Iwamoto, T., and Kita, K.: Amplification of light absorption of black carbon by organic coating, Aerosol Sci. Tech., 44, 46-54, 2010.

Slowik, J. G., Stainken, K., Davidovits, P., Williams, L. R., Jayne, J. T., Kolb, C. E., Worsnop, D. R.,Rudich, Y., DeCarlo, P. F., and Jimenez, J. L.: Particle morphology and density characterization by combined mobility and aerodynamic diameter measurements. Part 2: Application to combustion-generated soot aerosols as a function of fuel equivalence ratio, Aerosol Sci. Technol., 38, 1206-1222, 2004.
Slowik, J. G., Cross, E. S., Han, J.-H., Davidovits, P., Onasch, T. B., Jayne, J. T., Williams, L. R., Canagaratna, M. R., Worsnop, D. R., Chakrabarty, R. K., Moosmüller, H., Arnott, W. P., Schwarz, J. P., Gao, R.-S., Fahey, D. W., Kok, G. L., and Petzold, A.: An inter-comparison of instruments measuring black carbon content of soot particles, Aerosol Sci. Tech., 41, 295-314, 2007.

Song, C., Na, K., Warren, B., Malloy, Q., and Cocker, D. R.: Impact of propene on secondary organic aerosol formation from $\mathrm{m}$ xylene, Environ. Sci. Technol., 41, 6990-6995, 2007.

Stephens, M., Turner, N., and Sandberg, J.: Particle identification by laser-induced incandescence in a solid-state laser cavity, Appl. Opt., 42, 3726-3736, 2003.

Tang, S., Frank, B. P., Lanni, T., Rideout, G., Meyer, N., and Beregszaszy, C.: Unregulated emissions from a heavy-duty diesel engine with various fuels and emission control systems, Environ. Sci. Technol., 41, 5037-5043, 2007.

US EPA: Health Assessment Document for Diesel Engine Exhaust Center for Environmental Assessment, Office of Research and Development, US Environmental Protection Agency, Washington DC, 2002.

Volkamer, R., Jimenez, J. L., San Martini, F., Dzepina, K., Zhang, Q., Salcedo, D., Molina, L. T., Worsnop, D. R., and Molina, M J.: Secondary organic aerosol formation from anthropogenic air pollution: Rapid and higher than expected, Geophys. Res. Lett., 33, L17811, doi:10.1029/2006GL026899, 2006.

Walker, A. P.: Controlling particulate emissions from diesel vehicles, Top. Catal., 28, 165-170, 2004.

Weingartner, E., Saathoff, H., Schnaiter, M., Streit, N., Bitnar, B., and Baltensperger, U.: Absorption of light by soot particles: determination of the absorption coefficient by means of aethalometers, J. Aerosol Sci., 34, 1445-1463, 2003.

Weitkamp, E. A., Sage, A. M., Pierce, J. R., Donahue, N. M., and Robinson, A. L.: Organic aerosol formation from photochemical oxidation of diesel exhaust in a smog chamber, Environ. Sci. Technol., 41, 6969-6975, 2007.

Winkler, A., Ferri, D., and Hauert, R.: Influence of aging effects on the conversion efficiency of automotive exhaust gas catalysts, Catal. Today, 155, 140-146, 2010.

Zhang, Q., Worsnop, D. R., Canagaratna, M. R., and Jimenez, J. L.: Hydrocarbon-like and oxygenated organic aerosols in Pittsburgh: insights into sources and processes of organic aerosols, Atmos. Chem. Phys., 5, 3289-3311, doi:10.5194/acp-5-32892005, 2005. 